\author{
Milan Pelc \\ Institut za povijest umjetnosti, Zagreb
}

\title{
Panegyric Emblem Books, Jesuits and the Habsburg Emperors: Some Examples Related to $17^{\text {th }}$-Century Croatia
}

\author{
Original scientific paper - Izvorni znanstveni rad \\ Received - Primljen 14. 6. 2019. \\ UDK 096:7.045(497.52)+929.7(439)"16"
}

DOI 10.31664/ripu.2019.43.05

\begin{abstract}
This article presents several printed collections of panegyric emblems related to the Croatian cultural milieu as specific media intended to promote the Habsburg imperial house in the $17^{\text {th }}$ century. Emblem books were not printed in Croatia, but many of them were used, especially by Jesuits, as is documented in an $18^{\text {th }}$-century book inventory of the Zagreb Jesuit College's library (preserved in Budapest). Some of these emblem books are dedicated to the Habsburg emperors Ferdinand III and Leopold I. The only author of an emblem book from Croatia in the
\end{abstract}

$17^{\text {th }}$ century was Sebastian Glavinic (1632-1697), Bishop of Senj, who was educated at the Jesuit academies in Graz, Vienna, and Trnava. In Vienna, he published an epithalamic panegyric emblem book in honour of the wedding of Leopold I and Margaret of Spain in 1666, under the title Deplua charitum aurora augustissimi Phoebi Leopoldi augusto rore in Margaritam resoluta. By glorifying the imperial wedding in a medium that was accessible to the wider public, Glavinic could himself partake in the imperial glory, which also brought him certain benefits.

Keywords: emblems, Habsburg emperors, Jesuits, Sebastijan Glavinić

The spread and reception of the emblem culture in northern Croatia, an area under Habsburg rule, during the early modern period can be investigated on the basis of various types of visual, material or literary evidence. Emblem books in some historical libraries, for instance, offer an insight into the use of emblems in this period. Especially rich with such literature were three book collections: the library of the Croatian-Hungarian magnate Nikola Zrinski (Miklós Zrínyi), that of the Carniolan baron and polymath Johann Weichard Valvasor, and that of the Jesuit Academy in Zagreb. Each collection has been mutilated in its own way. A 1662 catalogue of the Zrinski library has been preserved in manuscript form, but most of the holdings have been lost. What remains is today part of the National and University Library in Zagreb. ${ }^{1}$ As for Valvasor's library, an important cultural acquisition of the Zagreb bishop Aleksandar Mikulić from about 1690, the books have largely remained preserved as a separate collection within the Library of the Zagreb Archdiocese (Bibliotheca Metropolitana), but there is no original catalogue from the time in which Valvasor's book collection was established. A modern catalogue was published in $1995 .{ }^{2}$ Unfortunately, several books containing emblems have been stolen - owing to their rich illustrations - in a robbery that took place in 1987. As for the library of the Jesuit College and Academy in Zagreb, an inventory from the late $18^{\text {th }}$ cen- tury has been preserved (today at the Budapest University Library), while the books themselves have been dispersed. Only a small number of them have been identified in other, mostly ecclesiastical collections in northern Croatia or in Hungary. ${ }^{3}$ Emblem books must also have existed in other private or ecclesiastical libraries, usually maintained by religious orders such as the Dominicans, Franciscans and Paulines. ${ }^{4}$ The use of emblems in other media, such as painting, sculpture, or artisan crafts, is likewise an important issue, but a comprehensive study based on these sources has yet to be undertaken. ${ }^{5}$

My aim here is to discuss several emblem books and prints related to the Croatian cultural milieu as instruments in a richly orchestrated concert intended to promote the Habsburg imperial house in the $17^{\text {th }}$ century. ${ }^{6}$ In the panegyric orchestra of $17^{\text {th }}$-century Habsburg absolutism, the loudest and most finely tuned instruments were certainly those of the Jesuits. It is a well-established fact that the Jesuits made a major contribution to the production and distribution of allegorical and emblematic literature during the century in question. ${ }^{7}$ The direct users of this production were hundreds and even thousands of pupils and students in Jesuit schools and universities throughout the Empire. ${ }^{8}$ The Habsburg rulers in this period were directly and powerfully influenced by the Society of Jesus. ${ }^{9}$ Wilhelm Germain Lamormaini, a 
distinguished and influential priest and rector of the Jesuit College in Vienna, was the personal confessor of Emperor Ferdinand II (1578-1637), whose Pragmatic Sanction of 1623 incorporated the Jesuit College into the University of Vienna. ${ }^{10}$ In 1640, the Pragmatic Sanction was confirmed by Emperor Ferdinand III. ${ }^{11}$ His successor to the throne, Leopold I, who has often been described as largely dependent on his Jesuit advisors, continued the policy of sponsoring the Jesuits and their schools. ${ }^{12}$ In return, the Jesuits acted as trustworthy and zealous glorifiers of the ruler and his family in all the available media, contributing to the construction of the imperial image. ${ }^{13}$

The role of the Society of Jesus in imperial promotion increased particularly with their takeover of the University of Vienna. Practically the entire educational system, from the lowest to the highest academic grade, along with numerous colleges and convents, was administered by the Jesuits. A small yet important cell in this large organism was the Jesuit College in Zagreb, established in 1606. It soon included a secondary school (a gymnasium, established in 1607), which had 400 pupils by the year $1615 \cdot{ }^{14}$ In 1662 , the College opened an Institute of Philosophy, which obtained the status of an academy in 1669, in a charter issued by Emperor Leopold I. Both the secondary school and the academy helped create a considerable audience for Jesuit panegyrics glorifying local noblemen and patrons, as well as the Emperor himself. In the records of the Historia Collegii Societatis Jesu in monte Graeco Zagrabiae siti (1606-1728), some typical examples of the Zagreb Jesuit College production can be found. For instance, in 1615 there is the earliest notice about panegyricas salutationes aliaque emblemata symbolica, produced in honour of Benedict Thuroczy, Banus (prorex) of Croatia. Numerous other opportunities followed for which panegyric emblems were required. For the most part they were dedicated to local noblemen as patrons of the Collegium Zagrabiense. ${ }^{15}$

Similar to other Jesuit universities, the Academy in Zagreb encouraged its doctoral candidates to publish their theses in print, as large poster sheets (Thesenblätter), which were then exhibited publicly and presented to distinguished individuals. ${ }^{16}$ Such sheets were usually commissioned from printers and editors in Augsburg. In documents, they are very often indicated as emblema. ${ }^{17}$ The first thesis defence in Zagreb took place in 1663 , following the foundation of the Faculty of Philosophy. ${ }^{18}$ Such learned "posters" were particularly suitable for the promotion of defendants' families, their patrons and the Emperor, as they glorified their persons not only before the pupils and students, but also before other recipients from the middle and higher classes, who gathered to attend the public defences of doctoral theses. Unfortunately, only a very small number of such engravings have been preserved in Croatia. ${ }^{19}$ One of them is a thesis by Ivan Josip Marburch (Marburg) from Rijeka, published under the title Theses ex universa Philosophia (1685). A copy in very large format (emblemate praegrandi), printed on silk, is nowadays kept at the Croatian History Museum in Zagreb (Fig. 1) ${ }^{20}$ Even though the thesis was dedicated to the estates of Carniola (inclytis Carnioliae statibus dedicato) due to the candidate's origin - as Rijeka was situated in Carniola at the time - Emperor Leopold I should be considered as its supreme patron.
He is depicted in armour in the upper central section, with the commander's staff and riding like a deus ex machina on an eagle amongst the clouds. ${ }^{21}$ It seems as though he is observing with benevolence the young defendant presenting his thesis in the lower left corner of the poster. At the beginning of the inscription held by the defendant he is addressed as the Austrian Jupiter, and his motto consilio et industria is inserted into the beginning of the dedication. Between the emperor and the defendant, a set of heraldic and allegoric motifs is assembled, which can easily be interpreted with the aid of the opulent inscriptions. On the right side, Fama with her trumpet is holding a dedicatory inscription which is in visual correspondence to the coats of arms on the left side: these are heraldic signs belonging to current high officials in Carniola. In the middle is the coat of arms of Georg Sigismund von Gallenberg, the current governor (locumtenens); around it are the coats of arms of four deputies (deputatis), whose names are honoured in the dedicatory inscription. In the middle is the personification of Carniola with its coat of arms and two eagles. On both sides of the lower part of the sheet, personifications of three cardinal virtues are depicted: Fortitude, Justice and Prudence. Above Fortitude, the personification of piety (pietas) with the incensory in her lap is presented. ${ }^{22}$ An angel behind this figure is holding the symbols of the Eucharist: a chalice and wafer. Between Fortitude and Temperance Vulcan is forging triumphal weapons - a symbolic allusion to the heroic deeds of Gallenberg and his ancestors. The stage for this richly arranged display of symbolic motifs is a big square ground framed by a "wall" of pyramids, which, according to the inscription on the left lower part of the thesis, denotes the military glory of the Gallenberg family. On the left side a significant motif is inserted: the Marian column in front of St. Jacob's, the Jesuit church in Ljubljana.

In this context, it is worth mentioning a second, and almost contemporary example from Zagreb, the thesis of Ladislav Esterházy. This thesis was defended at the Jesuit academy in 1681, under the Emperor's patronage. Only the lower half of this large poster has remained preserved, in which Emperor Leopold I is depicted in the centre with his Habsburg ancestors. Below him are the Hungarian palatine Paul (Pál) Esterházy, his son and the thesis defendant Ladislav, and various ancestors of the Esterházy family. The scene is flanked by a Marian column with the inscription Mariana pietate on the left, and the Holy Trinity column with the inscription Apostolico zelo, which emerges on the right. ${ }^{23}$

The column with the statue of the Immaculate Conception of Mary was erected in Ljubljana in 1682 as an ex voto made by the Carniolan estates in 1664 preceding the battle of St. Gotthard, in which the Ottomans were defeated by Christian forces. ${ }^{24}$ On Marburch's thesis the symbolism of the column, which is mentioned in the inscription, was clearly understandable and the column was recognisable to audiences in Zagreb and Ljubljana. The motif of the Marian column is spiritually related to the personification of prayer, but it also glorifies the piety of the Carniolian estates that erected it, and indirectly of Leopold I, who stimulated the veneration of the Immaculate Conception in the Empire with much zealousness. Thus, this part of the symbolic message on the thesis was of prime im- 


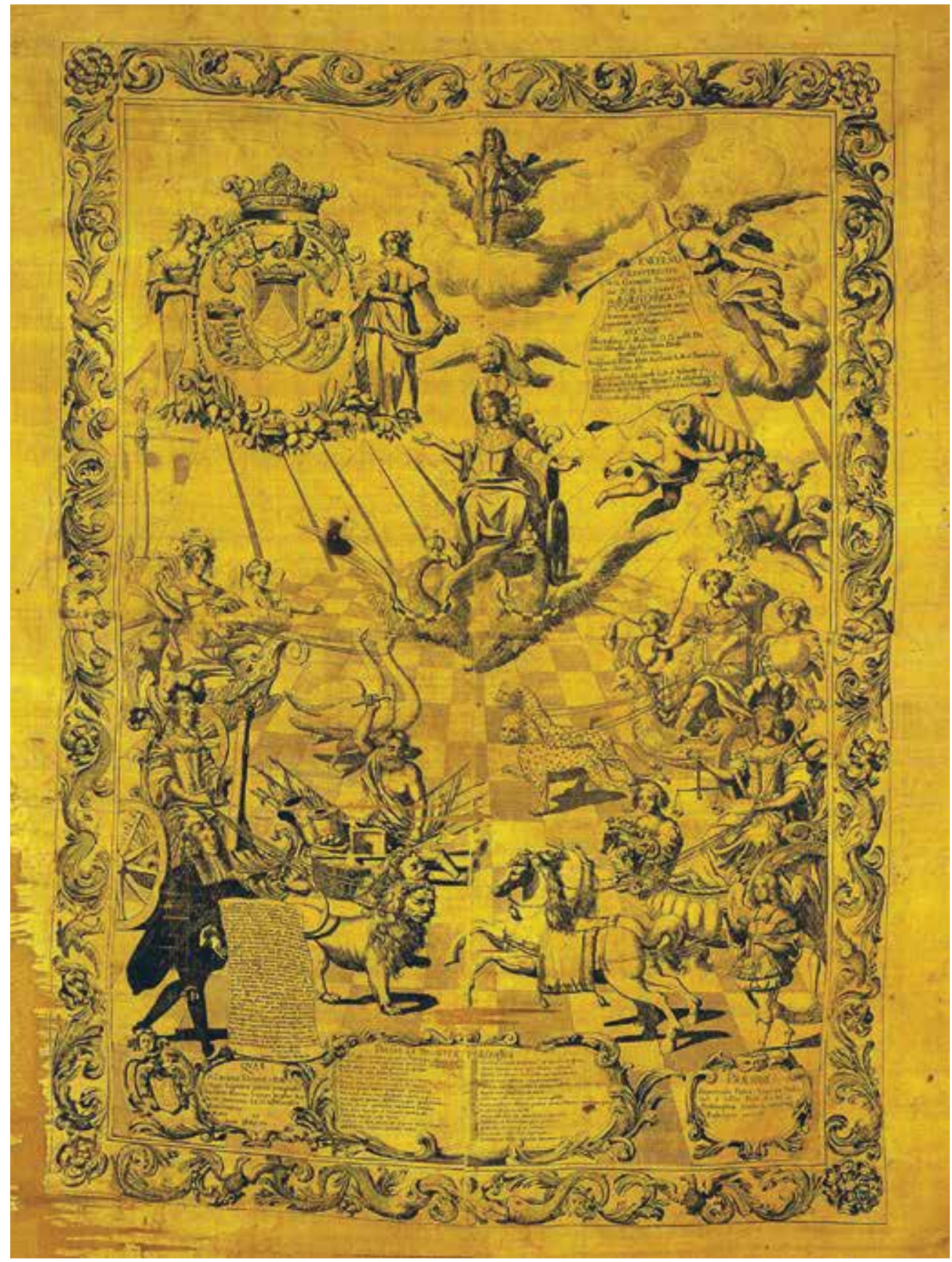

1. Ivan Josip Marburch (Marburg), Theses ex universa Philosophia, 1685, copper engraving print on silk, Zagreb, Croatian History Museum

Ivan Josip Marburch (Marburg), Theses ex universa Philosophia, 1685., bakrorez otisnut na svili, Zagreb, Hrvatski povijesni muzej

portance for the popularisation of Marian spirituality, which was promoted in wider communities of believers by religious orders such as the Franciscans and the Jesuits. ${ }^{25}$

Many of the symbols, personifications and allegories used in the theses of the period were idioms of a widespread pictorial language. As specific patterns of meaning they can easily be found in books with emblems of the period. In Zagreb and Croatia emblem books were not published, but acquired from elsewhere for the local Jesuit college. Thus, although they were not produced in Zagreb, panegyric books dedi- cated to the ruler and the imperial house were a substantial part of the Jesuit library's holdings. After the dissolution of the Society of Jesus in 1773, books from the libraries of Jesuit colleges in Croatia were dispersed and ended up in various institutions, and many were lost. Luckily, an inventory of the books which belonged to the Jesuit Academy in Zagreb from the late $18^{\text {th }}$ century has been preserved in Budapest. ${ }^{26}$ According to research conducted by Éva Knapp and Gábor Tüskés, the Jesuit Academy's library in Zagreb owned 102 emblem books from the $16^{\text {th }}-18^{\text {th }}$ centuries. In the inven- 


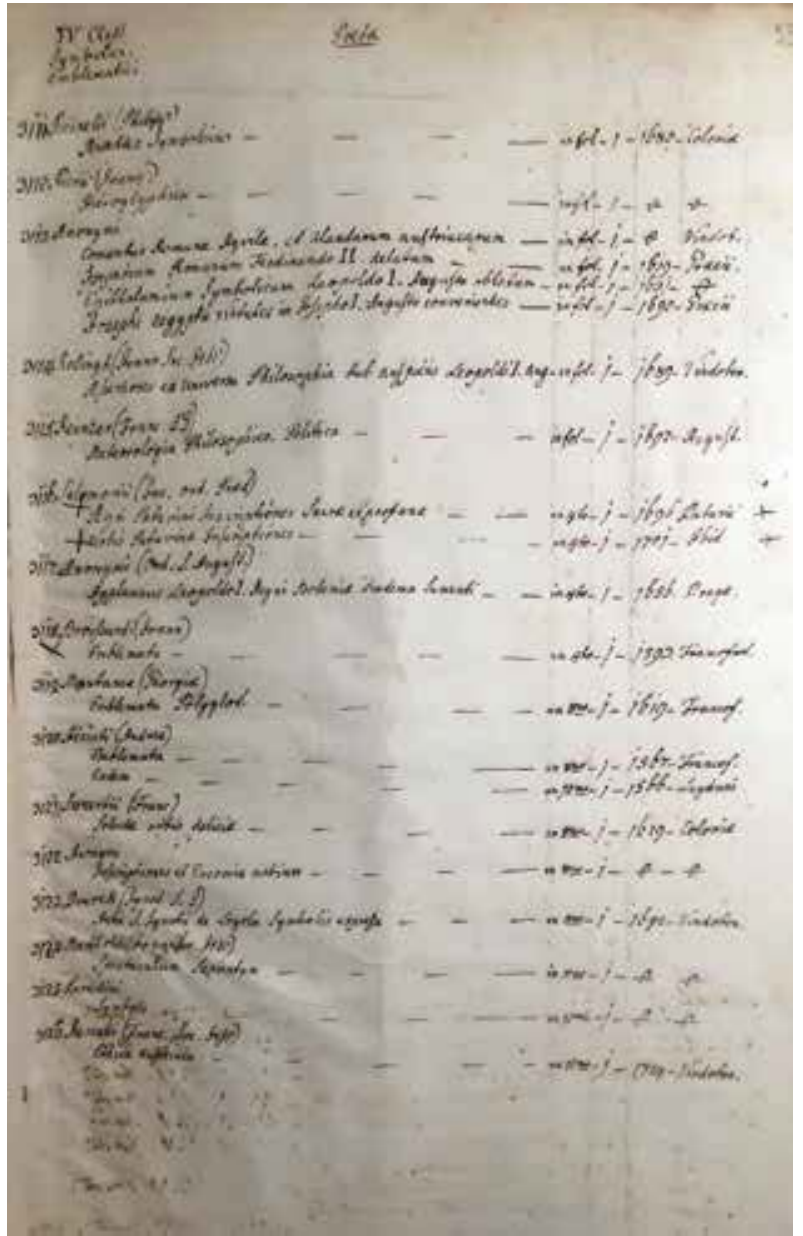

2. Catalogus Bibliothecae Zagrabiensis, 1782, section Poetae, Budapest, University Library (Egyetemi Könyvtár, Kézirattár): Coll. S. I., BEKK J 10/20

Catalogus Bibliothecae Zagrabiensis, 1782., sekcija Poetae, Budimpešta, Sveučilišna knjižnica (Egyetemi Könyvtár, Kézirattár): Coll. S. I., BEKK J 10/20

tory there is a division marked as Poetae, which contains a special section called Symbolici. Emblematici, listing books with symbolic and emblematic content (Fig. 2). This section lists 24 titles, including two editions of Alciati's famous Emblematum liber. Most of the listed emblem books date from the $17^{\text {th }}$ century. ${ }^{27}$

The listed titles of emblem books in the Budapest inventory include obvious examples of the panegyric and laudatory genre; the laudatio regularly referred to the Emperor. The occasions were mostly defences of doctoral theses by Jesuit students from the University of Vienna, held sub auspiciis imperatoris. The Zagreb College thus owned a special edition of a doctoral thesis by a Viennese doctoral candidate, Count Michael-Hermann Joseph Althann (1689), in the field of general philosophy: Assertiones ex universa philosophia. ${ }^{28}$ The frontispiece of this luxurious and expensive book, such as only a member of the rich lineage of Althann Counts could afford, features an allegorical portrait of Leopold I. ${ }^{29}$ The book begins with a list of 50 fundamental conclusions on the elements (Conclusiones elementares) proposed by the candidate. These are followed by various allegories and em-

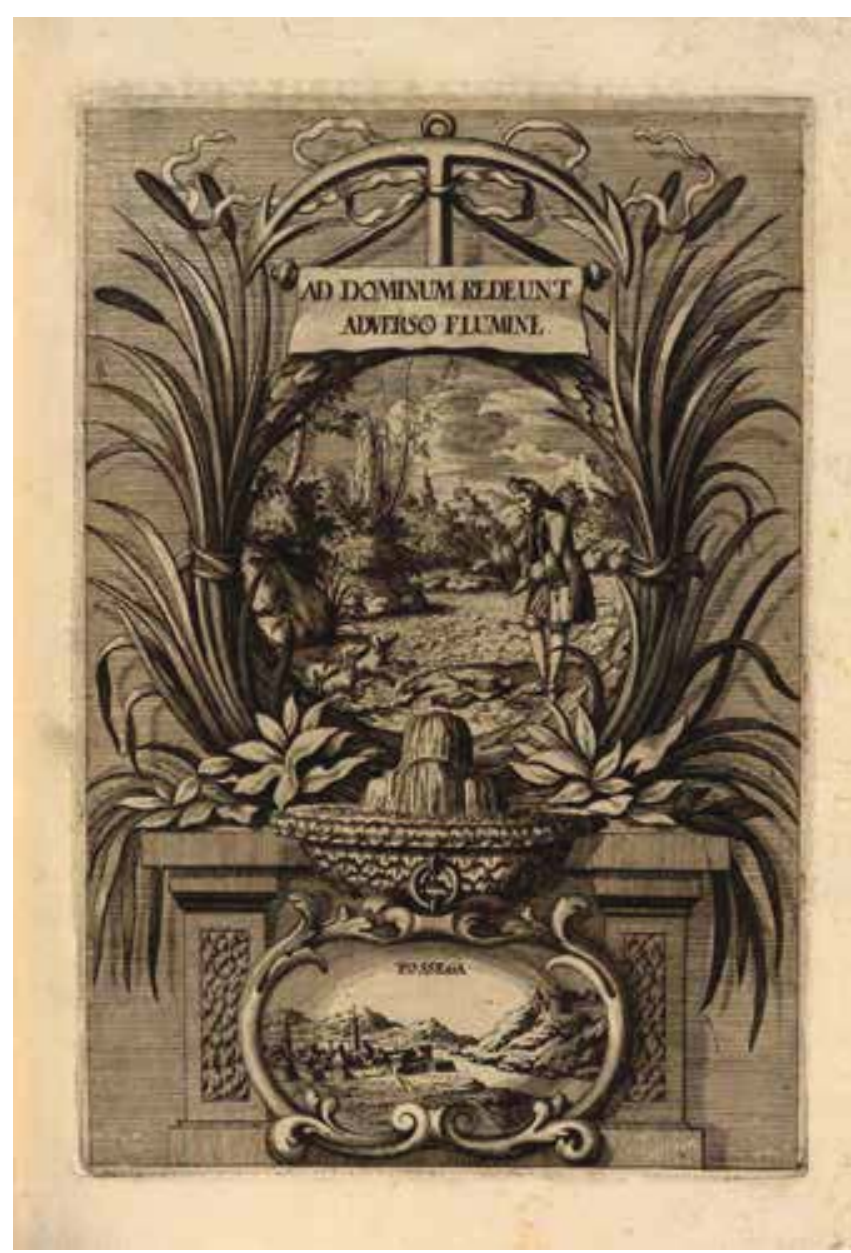

3. Michael-Hermann Joseph Althann, Assertiones ex universa philosophia, 1689, emblem with a view of Požega, Vienna, Austrian National Library / Österreichische Nationalbibliothek [Figs. 4-20 likewise] Michael-Hermann Joseph Althann, Assertiones ex universa philosophia, 1689., amblem s vedutom Požege, Beč, Austrijska nacionalna knjižnica [sl. 4-20 također]

blems with panegyric commentaries and poems, celebrating imperial victories over the Ottoman army in Hungary. Each emblem is linked to the liberation of a strategically crucial town, with its veduta in the lower section of the emblem image. These include three towns in Croatia (Slavonia): Požega, Darda and Osijek (Fig. 3-5). ${ }^{30}$ The emblem with a view of Mohács, where the Ottoman army suffered its final defeat in Hungary in 1687, shows the imperial eagle killing a Turkish hare, while another is leaping into the water and a third is fleeing into the forest (Fig. 6). The motto says: AUT FUGAT AUT NECAT AUT FATALES MERGIT IN UNDAS. In each of the accompanying poems, the author uses chosen words and plenty of learned allusions to mythology and history to explain the meaning of the emblem, thereby praising the Emperor and his military feats, which had led to the triumphal liberation of the Hungarian Kingdom. The military triumphs of the allied Christian forces in Hungary after 1683 were an inexhaustible source of all sorts of laudations, allegories, and panegyric emblems. ${ }^{31}$ Althann's publication of his doctoral thesis, transformed into a panegyric emblem collection, is only one among the numerous examples of this genre. 


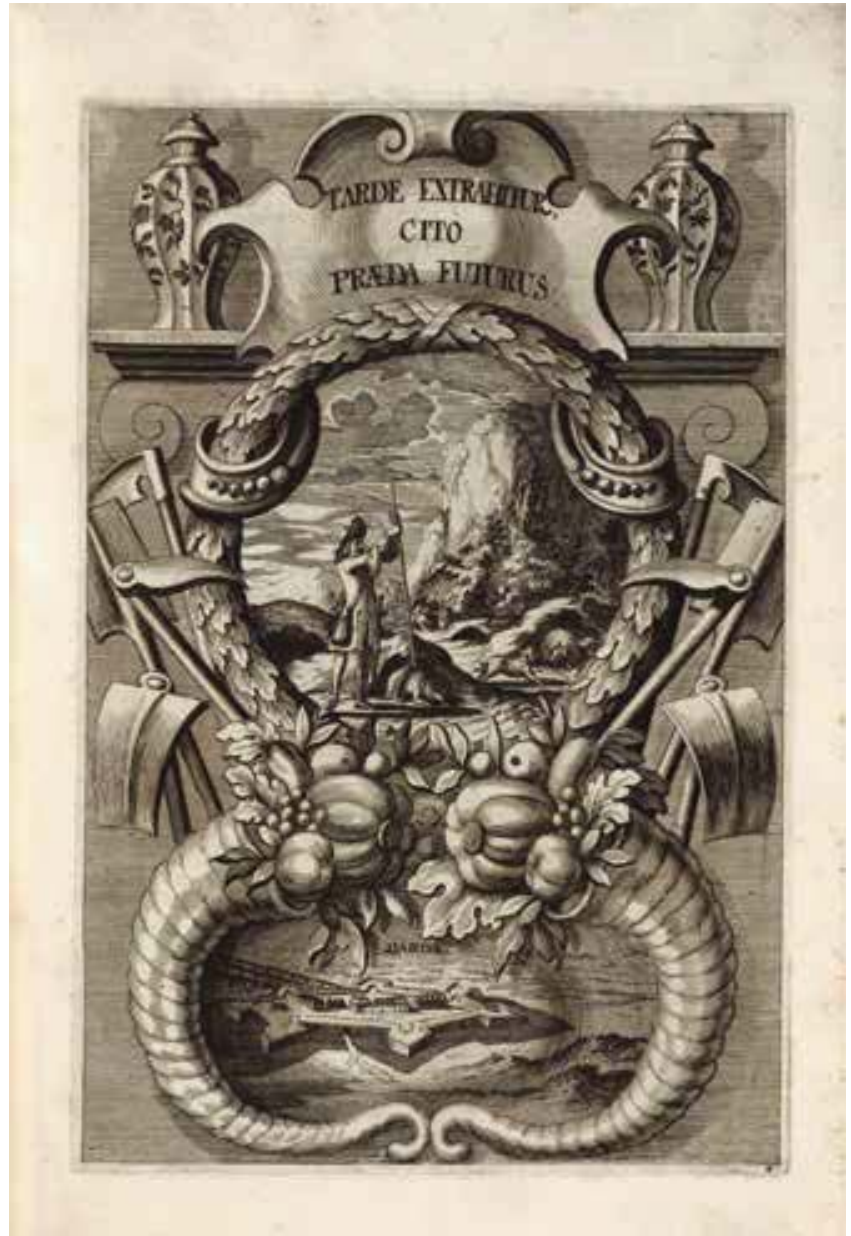

4. Michael-Hermann Joseph Althann, Assertiones ex universa philosophia, 1689, emblem with a view of Darda

Michael-Hermann Joseph Althann, Assertiones ex universa philosophia, 1689., amblem s vedutom Darde

Another entirely different and peaceful aspect of the lives of the Habsburg rulers in the $17^{\text {th }}$ century likewise inspired a number of emblem books and prints: imperial weddings. Epithalamic panegyric publications were an equally favoured medium for expressing admiration for the ruler in a decisive moment of dynastic history, in which marriage was expected both to ensure political alliances and to provide an heir to the throne. Such books and brochures addressed to the Habsburg emperors were indeed numerous in the $17^{\text {th }}$ century. ${ }^{32}$ Here I will present two examples of epithalamic panegyric emblem books produced by Jesuit authors, both of which can be associated with Croatia. The first is documented in the library inventory of the Zagreb College, in the aforementioned Poetae section. It is the book Epithalamium Symbolicum Leopoldo I. Augusto oblatum, printed in Graz in $1631 .^{33}$ The book has disappeared from Zagreb, but there is a copy preserved at the Austrian National Library, which gives us information on its full title, editors, and the place and date of publication. ${ }^{34}$ It was dedicated to King Ferdinand III (1608-1657) and his fiancée Maria Anna of Spain (1606-1646), and produced by the Jesuits from the College of Graz, who proudly emphasized the fact that Ferdinand had been their pupil and that they considered their college as his own. Educated until the age

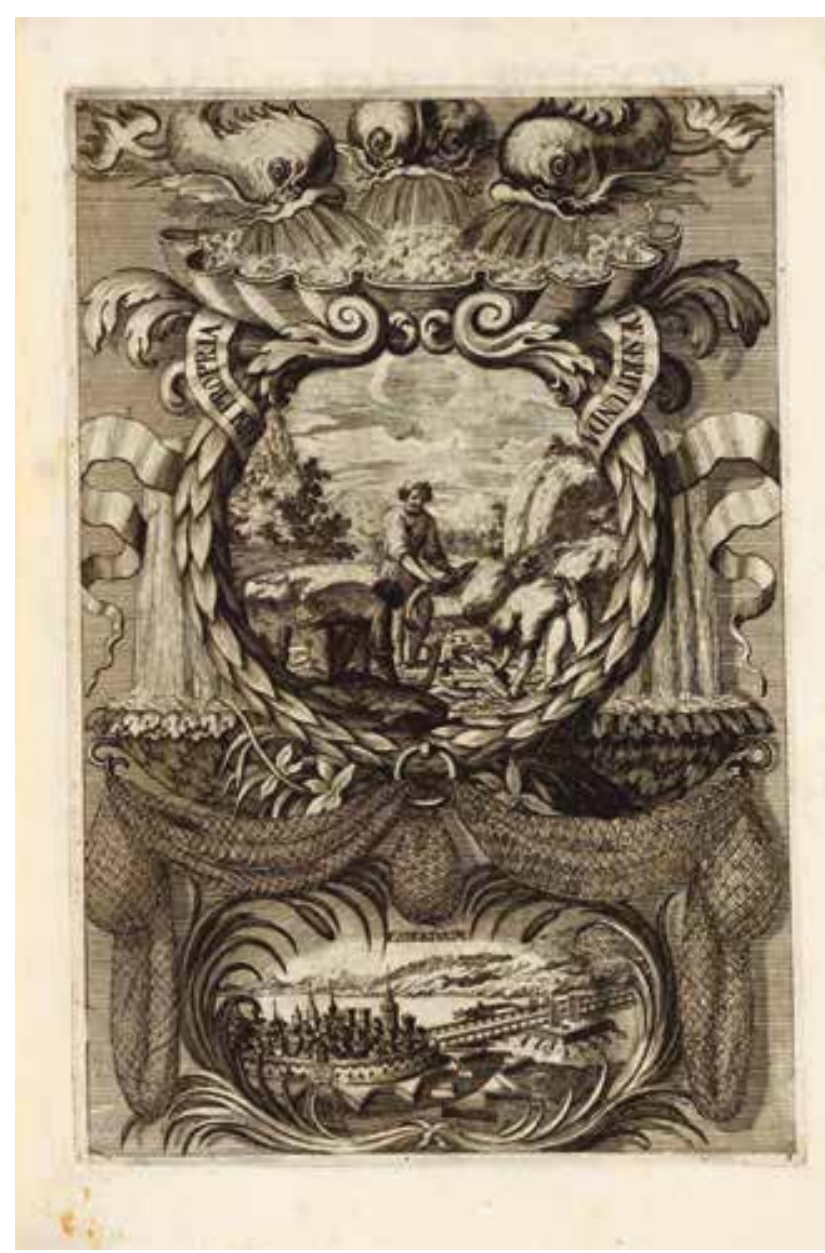

5. Michael-Hermann Joseph Althann, Assertiones ex universa philosophia, 1689, emblem with a view of Osijek

Michael-Hermann Joseph Althann, Assertiones ex universa philosophia, 1689., amblem s vedutom Osijeka

of eleven by the Jesuits of Graz, Ferdinand became King of Hungary and Croatia in 1625, King of Bohemia in 1627, and succeeded his father as the Holy Roman Emperor in 1637. On the $20^{\text {th }}$ of February 1631, Ferdinand III married his first wife, Archduchess Maria Anna of Spain, the youngest daughter of Philip III of Spain and Margaret of Austria. After her death, the Emperor married two more times.

This book, a collective product of the Jesuit College of Graz, contains 50 emblems with accompanying epigrams and explanations. The name(s) of the author(s) of images are not known, neither is the name of the engraver who prepared them for print..$^{35}$ The number 50 was symbolic: it was the number of years wished to the royal couple, and when they passed, they should be repeated once more. The content of the emblems reveals a typical mixture and fusion of humanist and religious scholarship: they abound in motifs from classical symbolism and mythology, including various astrological and zodiac symbols, with political allusions to the relations between Austria, Spain, Hungary and Rome, all to the benefit of the Catholic faith and the Empire. Thus, the emblem TUA POMA NEPOTES shows two intertwined apple trees full of fruit, a symbol of the Austrian-Spanish 


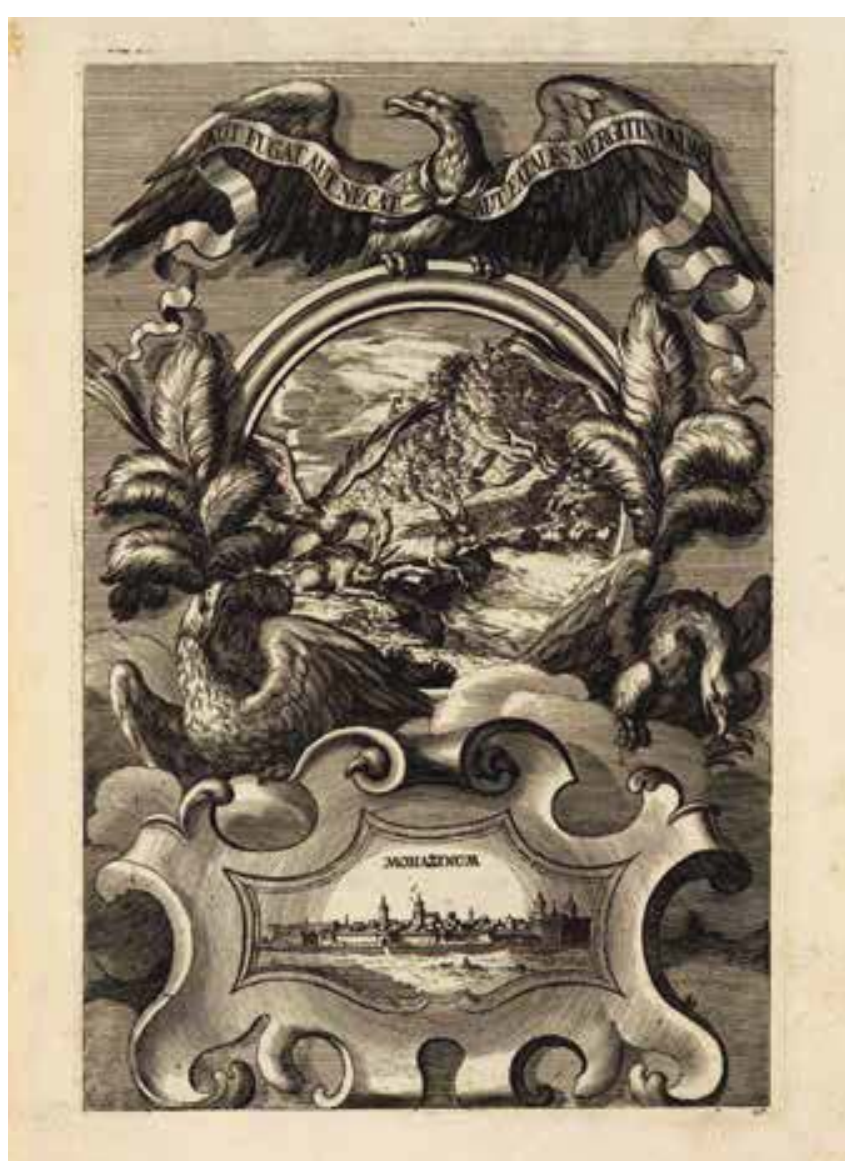

6. Michael-Hermann Joseph Althann, Assertiones ex universa philosophia, 1689, emblem with a view of Mohács

Michael-Hermann Joseph Althann, Assertiones ex universa philosophia, 1689., amblem s vedutom Mohača

alliance, which also alludes to the desired offspring of the imperial couple. The emblem AEDIFICAT DOMUM (Fig. 7) symbolizes the connection between all Habsburg lands - the heraldic symbols of various imperial territories (with Croatia and Dalmatia frontally positioned to the right) are depicted on square column bases. In the centre, there is the archducal coat of arms with a lyre on top. It is, as explained in the commentary, Amphion's lyre, which could bring dead stones to life with its gentle sound and make them build themselves into the walls of Thebe. This is an allusion both to the musical affinities of Ferdinand III and to his role in building up the Empire. ${ }^{36}$ The emblem DELICIAE REGIBUS symbolically extols the faith, the Eucharist, the name of Jesus, and thus the Society of Jesus itself. It recalls the delights of Christian piety (pietas), which are already enjoyed by the royal couple. At the same time, these are the delights of Austria and all its provinces, represented by cypress trees with coats of arms at their base, trees that grow in a perfectly ordered garden. Members of the college address a personal invocation to the royal couple in the emblem entitled VOTA COLLEGII (Fig. 8). Above an altar bearing the double sign of Christ's name, two hands hold rings with diamonds, which touch each other and have droplets falling from them, kindling the altar fire. An extensive commentary extols the good deeds and magnanimity (munificentia) of "Austrian virtue",

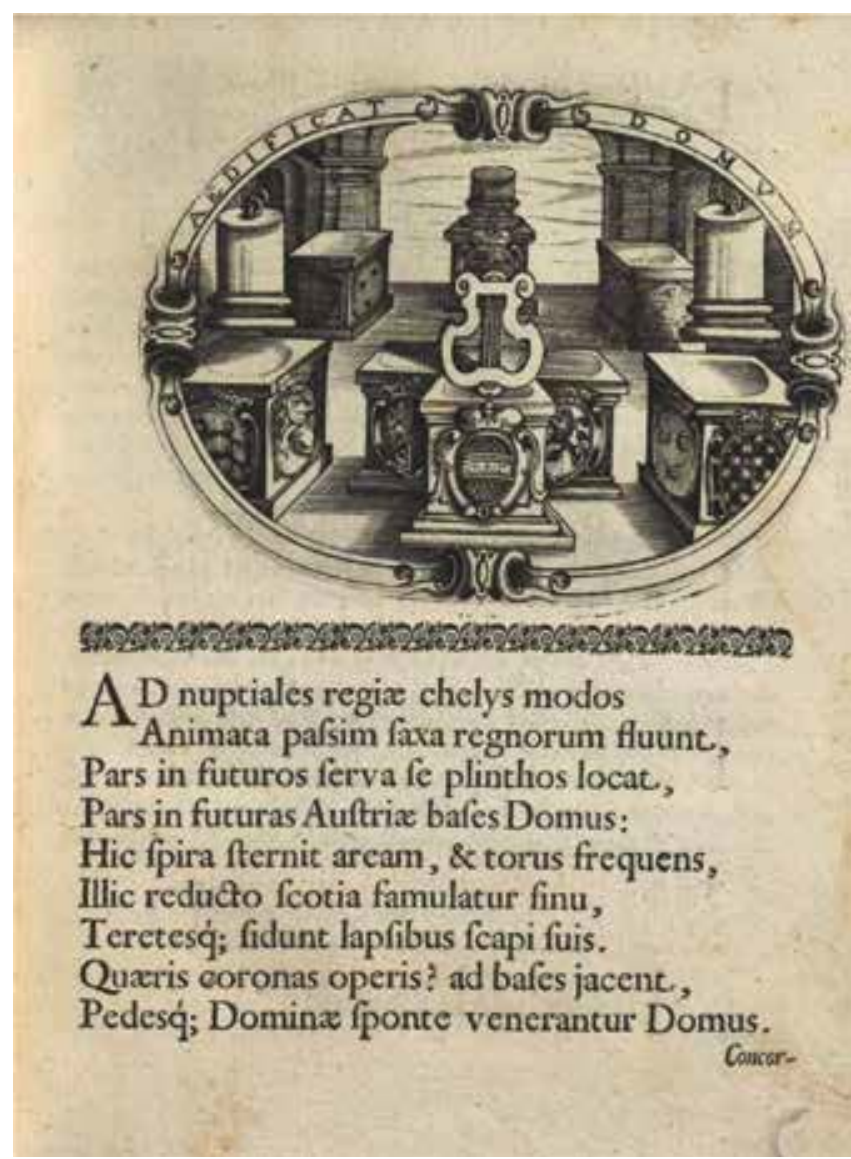

7. Epithalamium symbolicum conjugibus porphyrogenitis Ferdinando III Hungarorum Boemorumque regi, serenissimae Mariae reginae, 1631, emblem AEDIFICAT DOMUM

Epithalamium symbolicum conjugibus porphyrogenitis Ferdinando III Hungarorum Boemorumque regi, serenissimae Mariae reginae, 1631., amblem AEDIFICAT DOMUM

to which the Jesuits respond with eternal gratitude. ${ }^{37}$ This as well as other emblems with the name of Jesus, the Jesuits' own symbol, identify them symbolically with the virtus and pietas austriaca, while their gratitude corresponds to the authority bestowed upon them by the imperial house through its benevolence. The Jesuits of Zagreb, who were closely connected to the collegium Gracense, may have used this and other collections of emblems as sources for their own occasional production of similar symbolic content. They probably could not afford their own edition of panegyric emblems dedicated to the Emperor, but according to the catalogue of the Zagreb College, they were very well aware of the importance of such publications. ${ }^{38}$

The next example from the genre of epithalamic panegyrics was not produced directly by the Jesuits; however, it was created by a Croatian author who was educated by the Jesuits. Sebastijan Glavinić (1632-1697), born in a small town called Pićan in Istria, studied philosophy and theology at the Jesuit academies in Graz, Vienna, and Trnava (Tyrnau). ${ }^{39}$ In 1661-1662, Glavinić joined the imperial embassy to Moscow as a chaplain and priest. ${ }^{40} \mathrm{He}$ was soon appointed court chaplain in Vienna, where he stayed until $1677 .{ }^{41}$ Afterwards, he served as the senior parish priest in Slovenske Konjice 


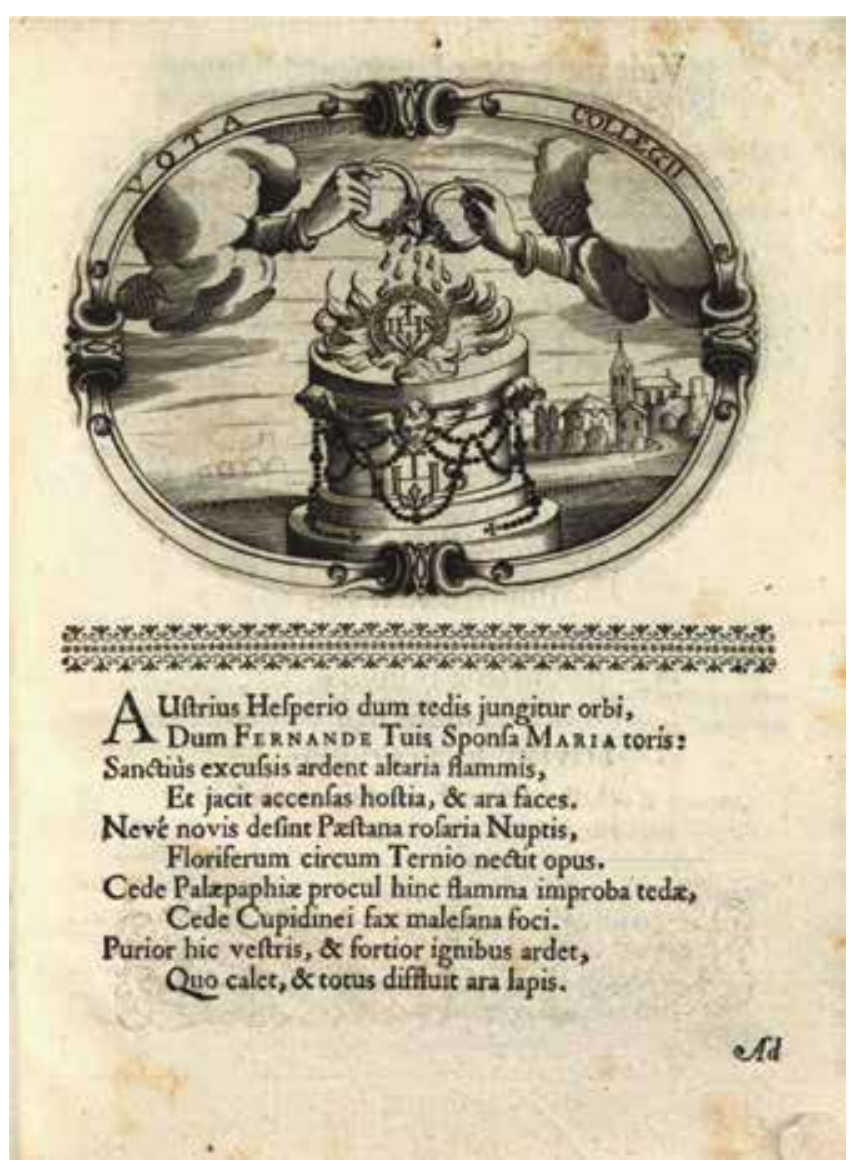

8. Epithalamium symbolicum conjugibus porphyrogenitis Ferdinando III Hungarorum Boemorumque regi, serenissimae Mariae reginae, 1631, emblem VOTA COLLEGII

Epithalamium symbolicum conjugibus porphyrogenitis Ferdinando III Hungarorum Boemorumque regi, serenissimae Mariae reginae, 1631., amblem VOTA COLLEGII

and in 1689 Emperor Leopold I appointed him Bishop of Senj and Modruš. It was as a court chaplain in Vienna that Glavinić, on the occasion of the Emperor's marriage with the Spanish princess Margaret Theresa in 1666, composed a panegyric brochure titled Deplua charitum aurora augustissimi Phoebi Leopoldi augusto rore in Margaritam resoluta with ten emblems dedicated to the imperial couple (Fig. 9). ${ }^{42}$ This is actually the only known emblem book from the $17^{\text {th }}$ century authored by a Croat, but unfortunately even in this case we do not know the author of the engravings. ${ }^{43}$ It is highly probable that Glavinić was inspired by the aforementioned 50 -emblem collection dedicated by the Jesuit College in Graz to the wedding of Leopold's parents, Emperor Ferdinand III and Mary of Spain.

One should also mention that the Graz College published a very luxurious occasional print with eleven emblems in folio dedicated to the wedding of Emperor Leopold I and Margaret of Spain, entitled Genealogia Serenissimae Domus Austriacae a Philippo Primo... ad Augustissimos Caesares Leopoldum et Margaretham deducta... dum felici et toto orbe desiderato hymenaeo jungerentur, Graz, Ferdinandus Widmanstadius (Widmanstetter), $1666 .{ }^{44}$ The exquisite engravings were probably designed by Albinus Patho, and

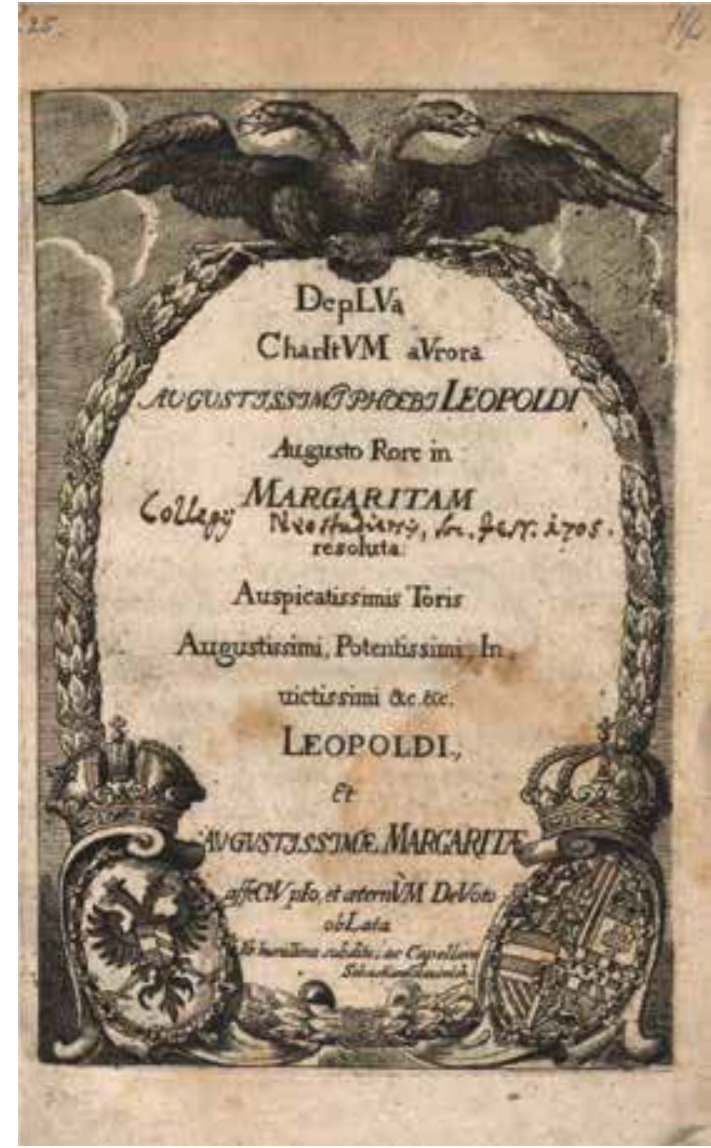

9. Sebastijan Glavinić, Deplua charitum aurora augustissimi Phoebi Leopoldi augusto rore in Margaritam resoluta, 1666, title page Sebastijan Glavinić, Deplua charitum aurora augustissimi Phoebi Leopoldi augusto rore in Margaritam resoluta, 1666., naslovnica

the engraver was Philipp Kilian, the famous printmaker from Augsburg. ${ }^{45}$ Perhaps Glavinić knew about this splendid emblem collection, but the visual form of his emblems, as well as the choice of symbolic motifs, share many characteristics with the emblems in 1631 Jesuit collection published in Graz, although Glavinićs images are still more modest. ${ }^{46}$ As a student, Glavinić may have seen it during his higher education at the Jesuit colleges of Graz, Vienna, or Trnava.

In his desire to honour the imperial couple and gain favour with Leopold I, Glavinić tried to be as innovative as possible, yet also reached for pre-existing motifs from traditional emblem handbooks. ${ }^{47}$ His chief sources of inspiration were Biblical tradition, ancient mythology, cosmology, and literature, which he related to the current occasion and suffused with pietas austriaca motifs as the "central commonplace of all Habsburg panegyrics." ${ }^{8}$ Interestingly, however, there are no allusions to the imperial triumphs against the Ottoman Turks, even though Glavinić could have referred to the glorious Christian victory in the battle of St. Gotthard (1664). This event was used, for example, by the author of the occasional emblem print published by the Graz College, where the emblem with the motto LUNA SUB PEDIBUS EIUS is dedicated precisely to this imperial victory. ${ }^{49}$

In his symbolic concept, Glavinić redundantly uses a play on words and meanings hidden in the name of the new 


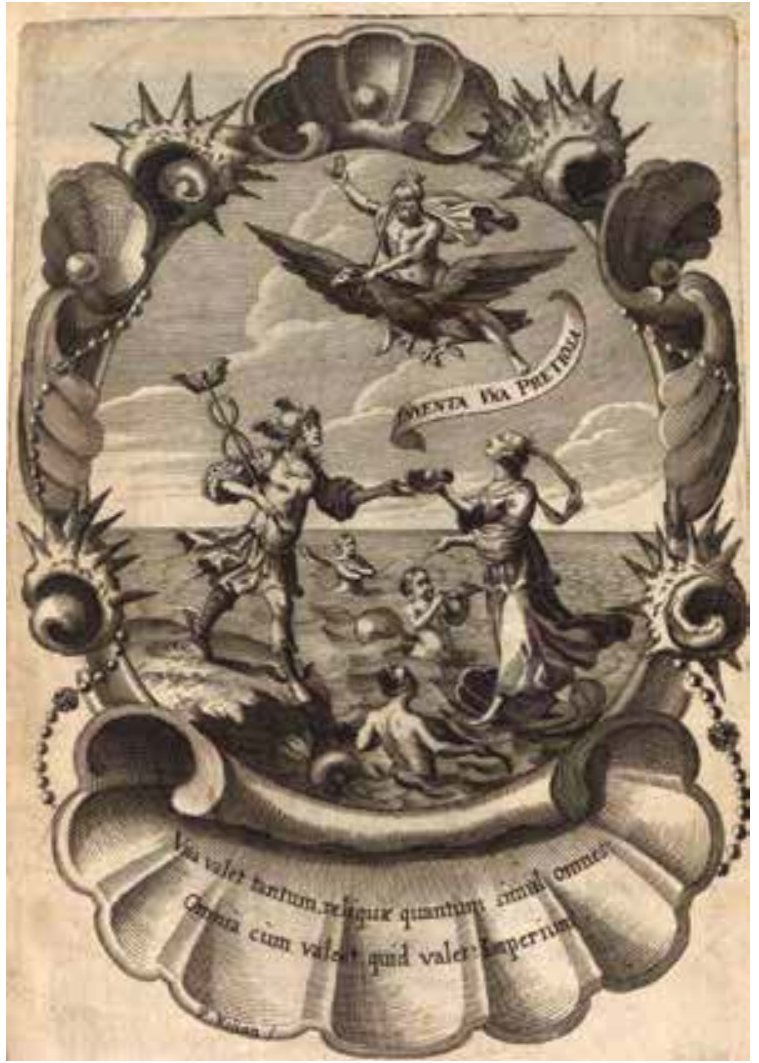

10. Genealogia Serenissimae Domus Austriacae a Philippo Primo... ad Augustissimos Caesares Leopoldum et Margaretham deducta... dum felici et toto orbe desiderato hymenaeo jungerentur, Graz, Ferdinandus Widmanstadius (Widmanstetter), 1666, emblem INVENTA UNA PRETIOSA

Genealogia Serenissimae Domus Austriacae a Philippo Primo... ad Augustissimos Caesares Leopoldum et Margaretham deducta... dum felici et toto orbe desiderato hymenaeo jungerentur, Graz, Ferdinandus Widmanstadius (Widmanstetter), 1666., amblem INVENTA UNA PRETIOSA

empress: Margarita = pearl. The pearl symbolizes perfection and purity as an untainted gift of nature. On the other hand, its meaning is linked to fertility (since it is drawn from the shell's womb) and can thus be interpreted as a token of the dynasty's survival. The pearl motif was also used in the last emblem of the Graz edition, which is entirely in the sign of the pearl: the young future empress is depicted as a nymph floating on a large shell (Fig. 10). At the command of Jupiter flying on an eagle, Mercury takes from her a small shell holding a pearl, and the whole scene is topped by a lemma declaring: INVENTA UNA PRETIOSA. The epigram at the bottom of the frame discreetly indicates that the genealogical fate of the Empire depends entirely on the new empress: Una valet tantum, reliquae quantum simul omnes // Omnia cum valent quid valet imperium..$^{50}$

As a gifted Latinist, Glavinić sought to amaze his readers with masterful versification. In his poems, composed in various metres and forms, the occasional chronograms, anagrams,

12. Sebastijan Glavinić, Deplua charitum aurora..., 1666, emblem USQUE AD ARAS

Sebastijan Glavinić, Deplua charitum aurora..., 1666., amblem USQUE AD ARAS

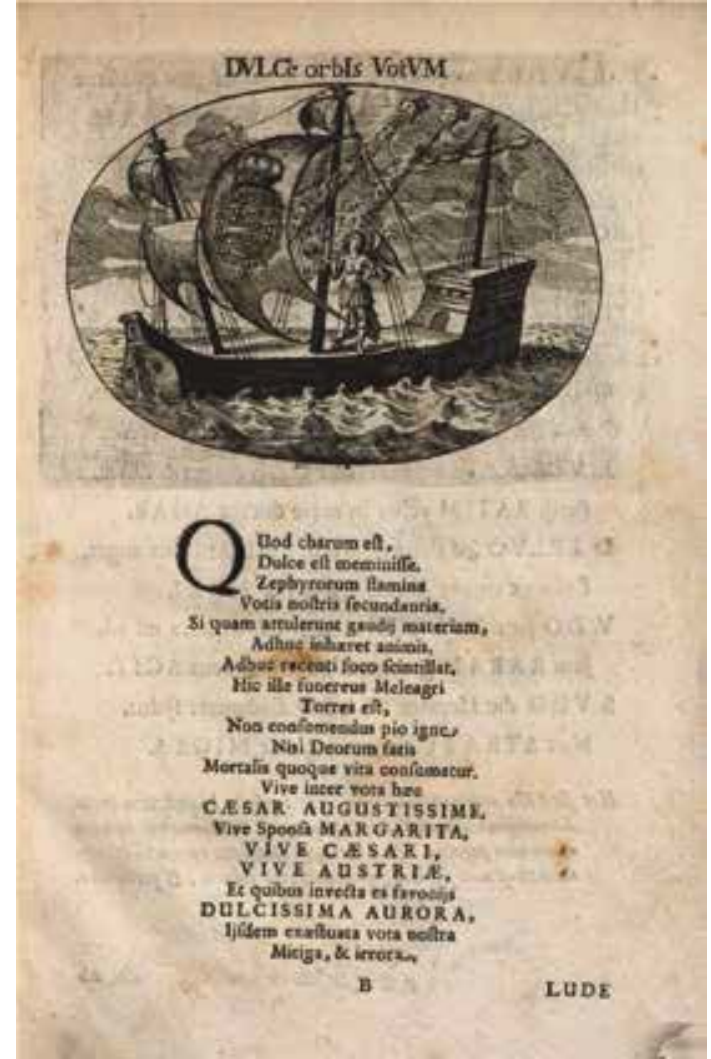

11. Sebastijan Glavinić, Deplua charitum aurora augustissimi Phoebi Leopoldi augusto rore in Margaritam resolute, 1666, emblem DULCE ORBIS VOTUM

Sebastijan Glavinić, Deplua charitum aurora augustissimi Phoebi Leopoldi augusto rore in Margaritam resolute, 1666., amblem DULCE ORBIS VOTUM

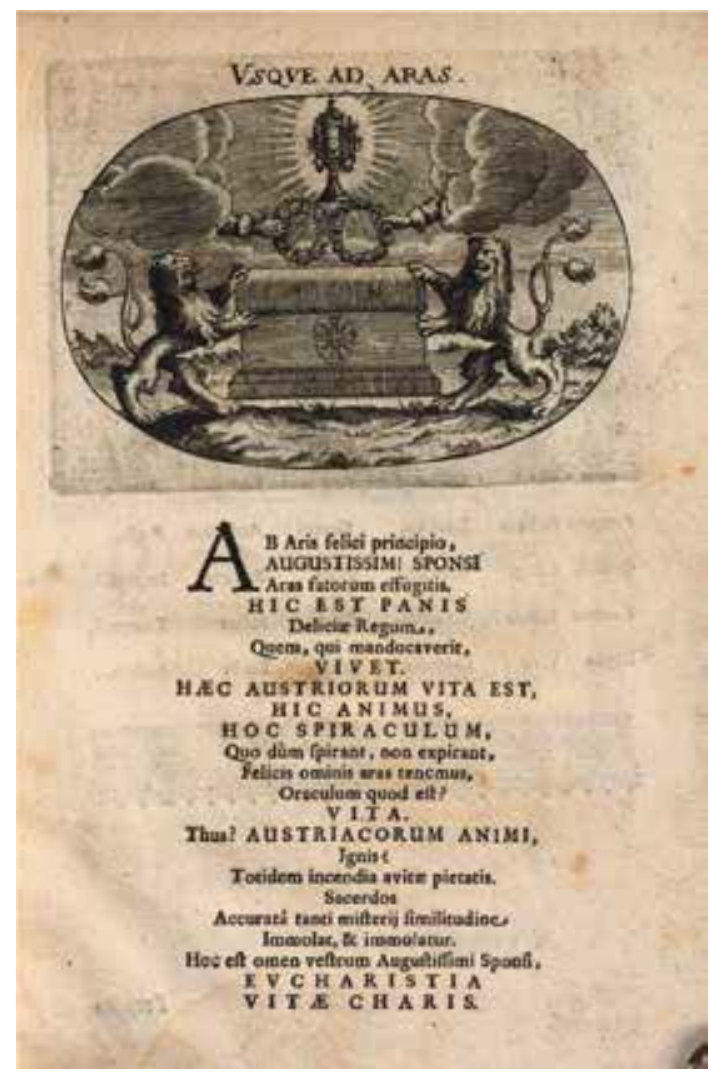




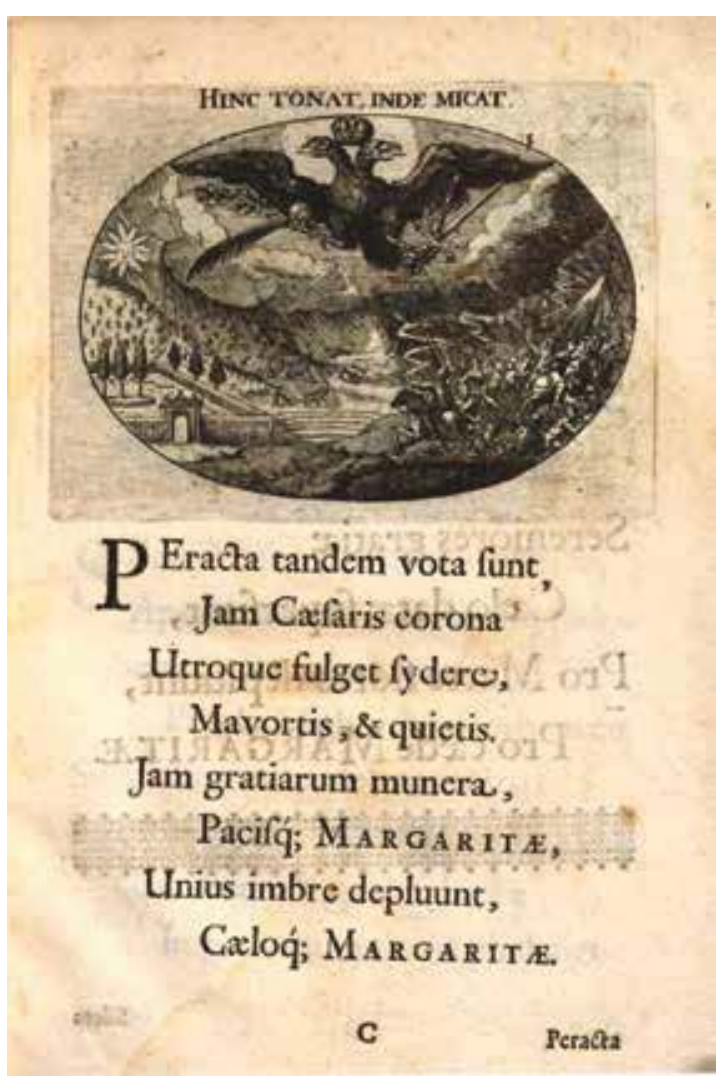

13. Sebastijan Glavinić, Deplua charitum aurora..., 1666, emblem HINC TONAT, INDE MICAT

Sebastijan Glavinić, Deplua charitum aurora..., 1666., emblem HINC TONAT, INDE MICAT

and acrostics are derived from the Emperor's and Empress's names, while his skilful ordering of words makes it possible to read the verses backwards, transversally, and so on. ${ }^{51}$ The first emblem, with the motto Dulce orbis votum (Fig. 11), shows Aurora standing on the deck of a galley bearing the Spanish coat of arms, and holding a pearl on her palm - the future empress, Margaret. The accompanying poem (carmen) is composed so as to alternate the names LEOPOLDUS and MARGARITA in each line.

The second emblem, with the motto Usque ad aras (Fig. 12), shows an altar supported by lions on both sides, which alludes to the Habsburgs as the guardians and defenders of faith. ${ }^{52}$ Above the altar, hands are protruding from the clouds, holding two wreaths of roses symbolizing the wedded couple, and a monstrance with the host, a symbol of the Eucharist, floats above them. This indicates the dynasty's Catholic zealousness. The word Eucharistia was often interpreted as Hic Austriae, and here, in the final verses of the accompanying poem, it is interpreted as Vitae Charis. ${ }^{53}$ The representation and veneration of the Eucharist had political implications as well. The monstrance was often designed as a sun with radiant beams, and that was also the way in which absolutist rulers, in this case Leopold I, were frequently depicted: in a nimbus with sunbeams. Moreover, the Eucharistic sun was often contrasted with the Ottoman moon. To the observer's mind, this automatically brought the imperial triumph over the sworn enemy of Christianity. ${ }^{54}$

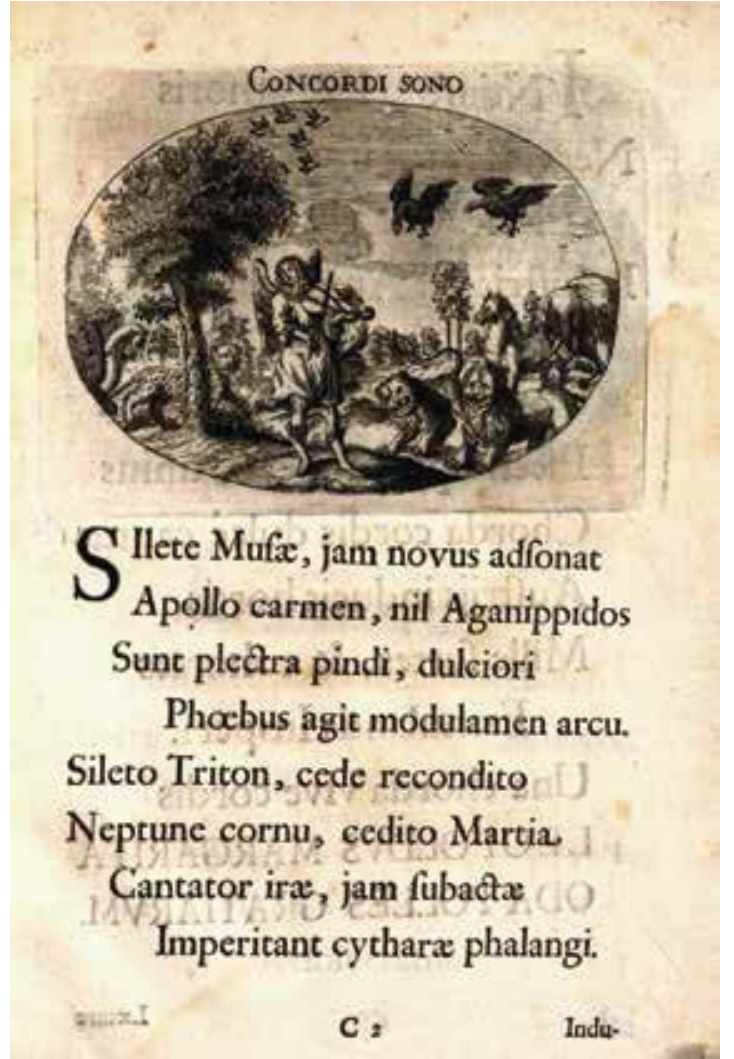

14. Sebastijan Glavinić, Deplua charitum aurora..., 1666, emblem CONCORDI SONO

Sebastijan Glavinić, Deplua charitum aurora..., 1666., amblem CONCORDI SONO

In the third emblem, with the motto Hinc tonat, inde micat (Fig. 13), an idyllic, sunlit landscape of peace and affluence is shown in the background to the left, and the chaos of war in front to the right. The imperial eagle is flying above the scene, with the symbols of prosperity and new alliance in the claws of its right leg - palm and laurel branches, and a pearl - whereas in its left it is holding a sword, a sceptre, and Jupiter's thunderbolts as the symbols of warfare and triumph over enemies.

The fourth emblem, with the motto Concordi sono (Fig. 14), shows Apollo playing his viola surrounded by various animals, with two lions in front. Two eagles are flying in the sky: they represent the imperial couple that will, as explained in the accompanying poem, intone a new song of love and concord.

The fifth emblem, with the motto Veni auster perfla hortum (Fig. 15), invokes the south wind, which brings soothing rain and fertility over Austria, depicted as a well-ordered and harmonious garden. The emblem alludes to the fertility of the imperial couple, which is to rejuvenate all of Austria and make it blossom.

The sixth emblem, with the motto Ab ignibus ignes (Fig. 16), shows the imperial lion holding two pearls, Leopold and Margaret, linked by a ring from which rays of light emanate and illuminate various cities of the Empire. This emblem likewise alludes to the future offspring of the imperial 


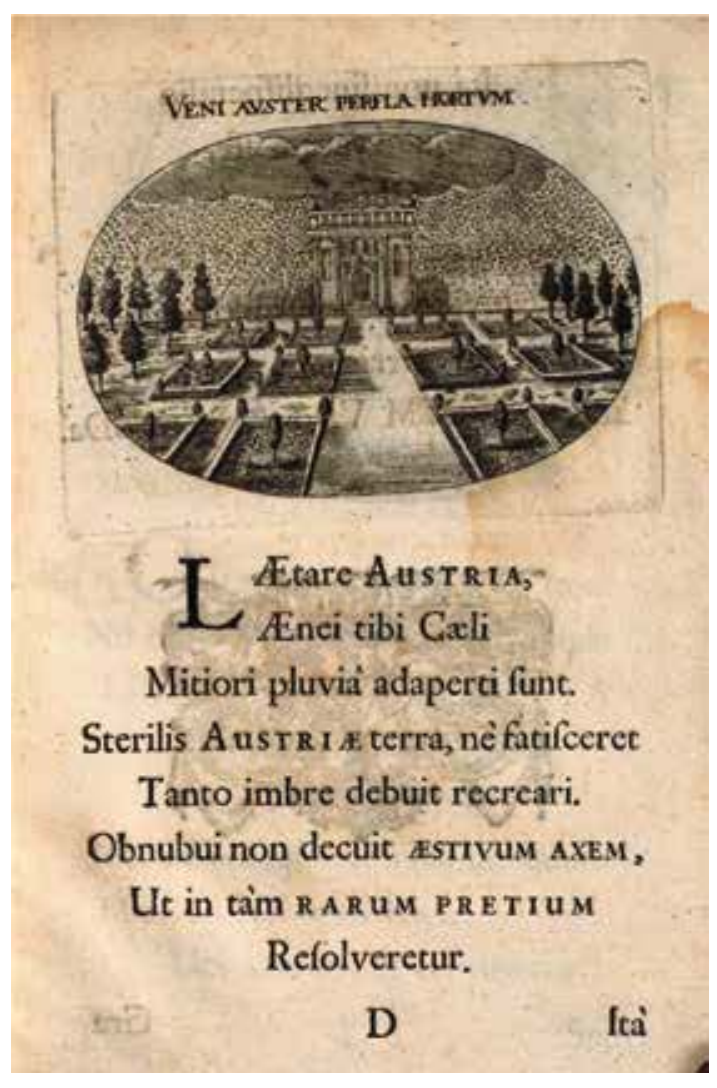

15. Sebastijan Glavinić, Deplua charitum aurora..., 1666, emblem VENI AUSTER PERFLA HORTUM

Sebastijan Glavinić, Deplua charitum aurora..., 1666., amblem VENI AUSTER PERFLA HORTUM

couple. The accompanying verses refer to the Emperor as Neo-Jupiter and to the Empress as Neo-Minerva.

The seventh emblem, with the motto Omni pretiosior auro (Fig. 17), shows Victoria (or Aurora) carrying a large pearl towards two crowned columns, with the motto Consilio et Industria - the symbol of the Emperor himself. Consilium refers to his wise governance and industria to his relentless warfare against the enemy. ${ }^{55}$ With the arrival of the precious pearl, Margaret, the Emperor will obtain additional support in his double duty.

The eighth emblem, with the motto Pro aris et focis (Fig. 18), shows a crane holding a pearl in its raised leg. The crane is an ancient symbol of vigilance over the homeland and the faith, and is used very frequently in emblems. ${ }^{56}$ Usually it holds an ordinary stone, but here the stone has been replaced by a precious pearl in allusion to the name of the new empress.

The ninth emblem, with the motto Regali convivia luxu (Fig. 19), shows Fama holding a pearl in her right hand, flying on an eagle, while in her left she is holding a trumpet with

17. Sebastijan Glavinić, Deplua charitum aurora..., 1666, emblem OMNI PRETIOSIOR AURO. Vienna, Österreichische Nationalbibliothek

Sebastijan Glavinić, Deplua charitum aurora..., 1666., amblem OMNI PRETIOSIOR AURO

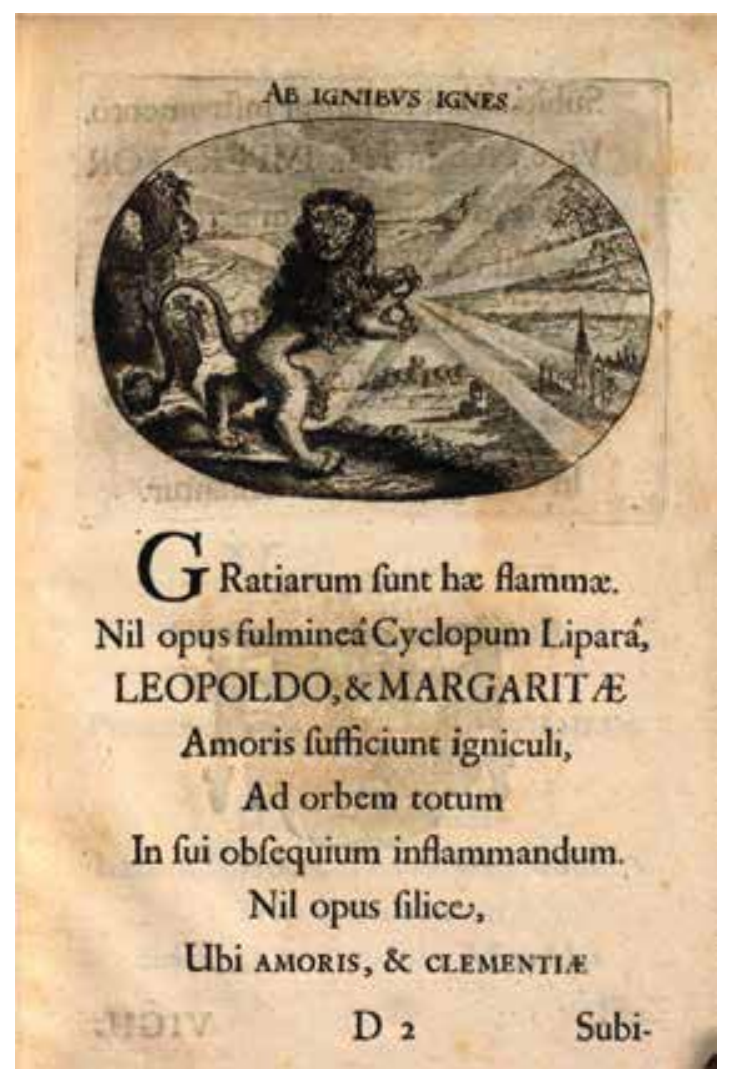

16. Sebastijan Glavinić, Deplua charitum aurora..., 1666, emblem AB IGNIBUS IGNES

Sebastijan Glavinić, Deplua charitum aurora..., 1666., amblem $A B$ IGNIBUS IGNES 


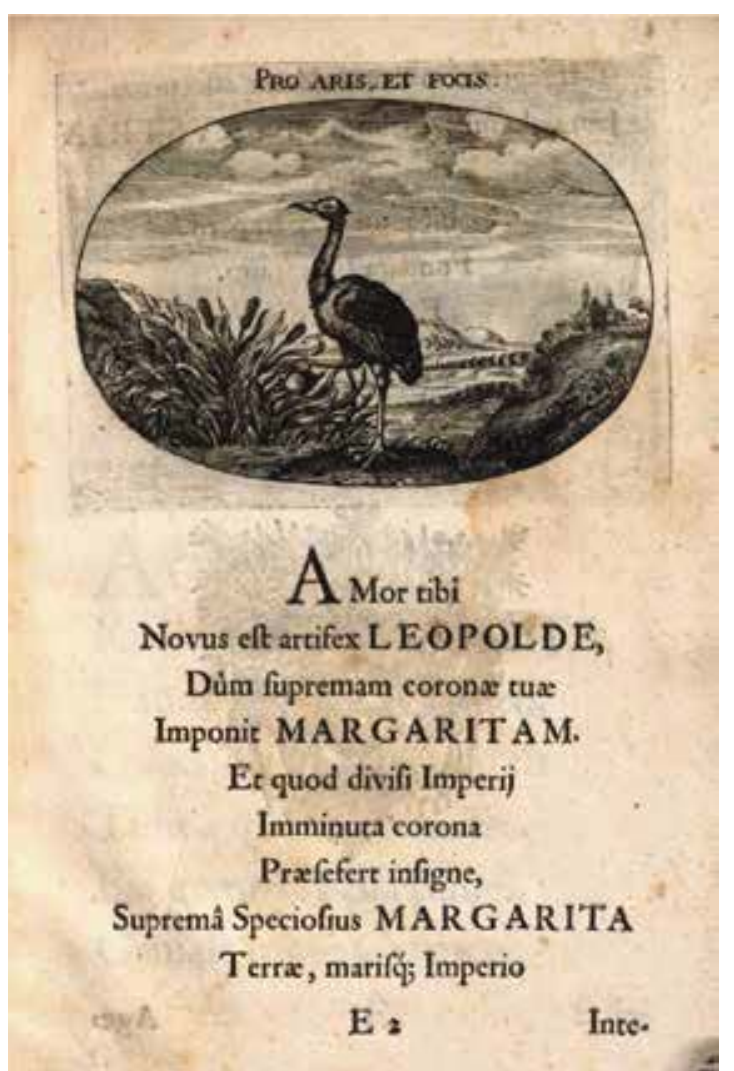

18. Sebastijan Glavinić, Deplua charitum aurora..., 1666, emblem PRO ARIS ET FOCIS

Sebastijan Glavinić, Deplua charitum aurora..., 1666., amblem PRO ARIS ET FOCIS

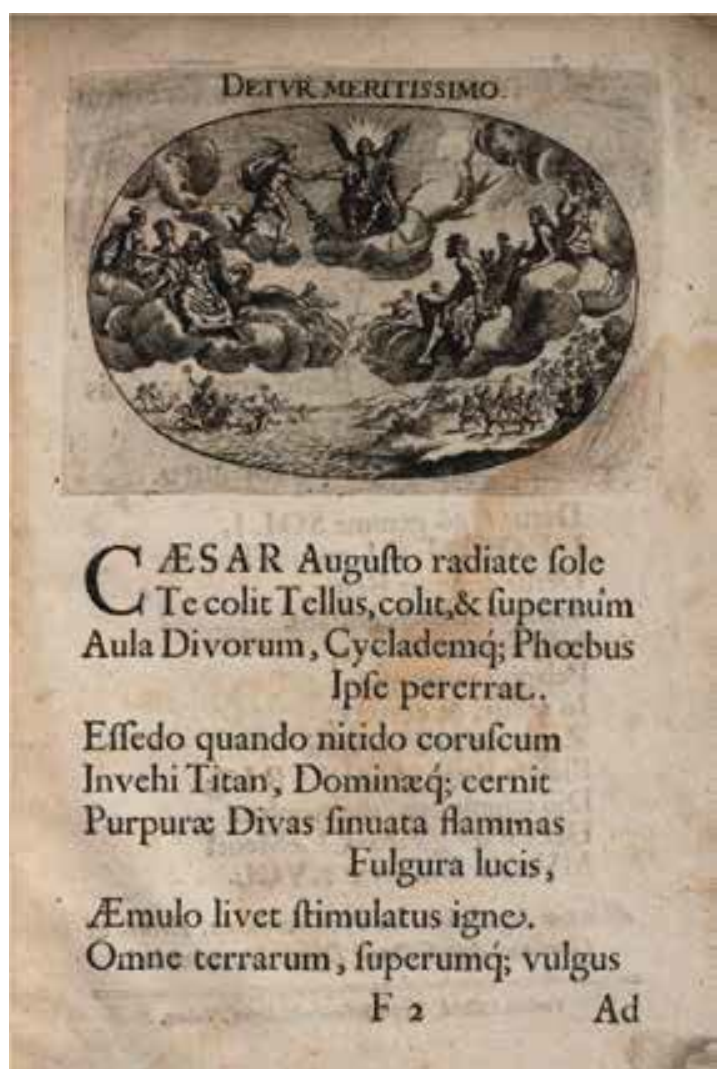

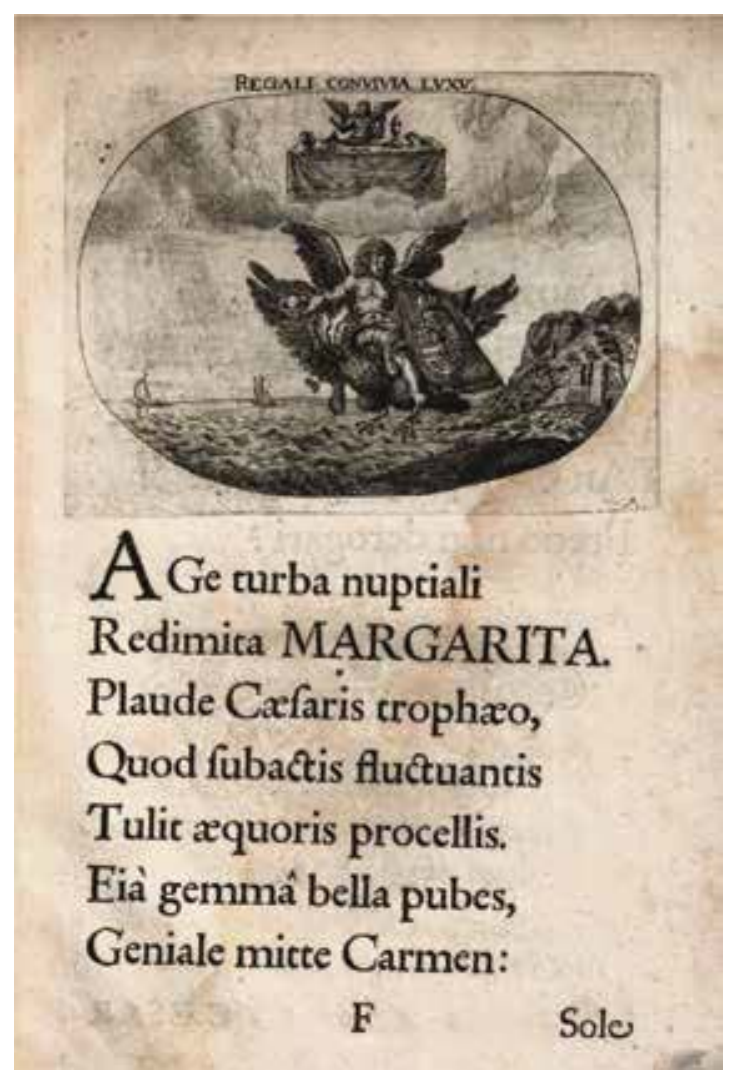

19. Sebastijan Glavinić, Deplua charitum aurora..., 1666, emblem REGALI CONVIVIA LUXU

Sebastijan Glavinić, Deplua charitum aurora..., 1666., amblem REGALI CONVIVIA LUXU

the Spanish coat of arms. She is bringing the joyful news to the world. Above her, in the clouds, there is an altar with liturgical vessels and an angel behind it - a symbol of God's presence and an invitation to the wedded couple to partake in the heavenly feast.

The tenth emblem, with the motto Detur meritissimo (Fig. $20)$, shows an assembly of deities. In the centre, enthroned in the midst of the clouds, there is Phoebus (Apollo with his lyre). This is actually Leopold, whom Mercury presents with a pearl - Margarita. The idea of Mercury with the pearl was probably taken from the last emblem in the Graz collection (Fig. 10). All gods, the heaven and the earth, are subjected to the Sun-Emperor and they all rejoice at his wedding.

Glavinićs epithalamic occasional print fits seamlessly into the tradition of emblem panegyrics dedicated to the imperial house of Habsburg. His booklet closes with the exclamation: Ad majus Augustissimorum Neo-Sponsorum, Decus, et Gaudium, Augustissimaeque Domus Incrementum! As a private person in the imperial service, Glavinić obviously believed that by showing his loyalty in these terms he could secure his position at court and obtain new favours. This

20. Sebastijan Glavinić, Deplua charitum aurora..., 1666, emblem DETUR MERITISSIMO

Sebastijan Glavinić, Deplua charitum aurora..., 1666., amblem DETUR MERITISSIMO 
indeed happened: in 1689, Leopold I remembered his former chaplain and appointed him Bishop of Senj and Modruš when the diocese was freed from the Ottomans. One of the reasons may well have been the panegyric emblem booklet, with which Glavinić, a Jesuit student and a follower of Jesuit poetical flattering, showed an exemplary use of skills in com- plimenting his ruler. Playing with various motifs of visual and poetic symbolism, he thus joined the legion of promoters of imperial power. By glorifying the imperial wedding in a medium that was accessible to the wider public, he could himself partake in the imperial glory, which also brought him certain benefits. ${ }^{57}$

\section{Notes}

* This paper is an extended and elaborated version of work presented at the conference The Power of Media. Patronage, Representation and Propaganda in Early Modern Period (1450-1800) between the Mediterranean and Central Europe (Split, June 13-15, 2018).

\section{1}

See: TIBOR KLANICZAY, A bibliotheca Zriniana története és állománya. History and Stock of the Bibliotheca Zriniana, Budapest, 1991; IVAN KOSIĆ, Bibliotheca Zriniana, in: Plava krv, crna tinta. Knjižnice velikaških obitelji od 1500. do 1700. [Blue Blood, Black Ink, Book Collections of Aristocratic Families from 1500 to 1700], Zagreb and Budapest, 2005, 17-39.

2

See: VLADIMIR MAGIĆ - BOŽENA KUKOLJA, Bibliotheca Valvasoriana. Katalog knjižnice Janeza Vajkarda Valvasorja [Bibliotheca Valvasoriana. The catalogue of Janez Vajkard Valvasor's library], Ljubljana and Zagreb, 1995. Emblem books from Valvasor's library will be the topic of a separate study (by the author, in preparation).

See: VLADIMIR MAGIĆ, Prilog poznavanju knjižnice Isusovačkog zavoda (kolegija) u Zagrebu [Library of the Jesuit College in Zagreb: a contribution to its research], u: Tkalčić, godišnjak Društva za povjesnicu Zagrebačke nadbiskupije, 11 (2007), 665674; ÉVA KNAPP - GÁBOR TÜSKÉS, Emblematics in Hungary: A Study of the History of Symbolic Representation in Renaissance and Baroque Literature, Tübingen, 2003, 41.

4

For example, an exceptionally important emblem book was found at the library of the Franciscan monastery in Kraljeva Sutjeska (today Bosnia and Herzegovina). See: SANJA CVETNIĆ, Andrea Alciato: Emblemata s opsežnim komentarima iz 1621. u Bosni Srebrenoj [Andrea Alciato's Emblemata edition from 1621 with extensive commentaries in Bosna Argentina], in: Bosna Franciscana, 28 (2008), 151-162.

\section{5}

In Croatia, there are only a few studies on this topic, mostly focusing on some specific examples from $16^{\text {th }}$ and $18^{\text {th }}$ century painting. See: MILAN PELC, Freske u ljetnikovcu nadbiskupa Lodovica Beccadellija na Šipanu [Frescos in the summerhouse of Archbishop Lodovico Beccadelli on the island of Šipan], in: Umjetnički dodiri dviju jadranskih obala u 17. i 18. stoljeću, (eds.) V. Marković and I. Prijatelj Pavičić, Split, 2007, 159-173; TANJA TRŠKA MIKLOŠIĆ, Lodovico Beccadelli i likovna kultura Bologne u dubrovačkom kontekstu [Lodovico Beccadelli in Dubrovnik and the Visual Culture in Bologna], in: Sic ars deprenditur arte. Zbornik u čast Vladimira Markovića, (eds.) S. Cvetnić, M. Pelc and D. Premerl, Zagreb, 2009, 529-538, especially 535; SANJA CVETNIĆ, Simboli, alegorije i emblemi u zidnom slikarstvu Johannesa Baptiste Rangera [Symbols, allegories, and emblems in the mural painting of Johannes Battista Ranger], in: Religijske teme u likovnim umjetnostima, (ed.) I. Antunović, Zagreb, 2004, 69-78; SANDA MILOŠEVIĆ, Alegorijski i emblematski prizori u opusu Ivana Krstitelja Rangera [Allegorical and emblematic scenes in the oeuvre of Johannes Battista Ranger], MA thesis, University of Zagreb, 2004.

6

The scholarly bibliography on emblems is enormous. There is no unique or generally accepted definition of emblems. They are often interpreted as variants of symbols and allegories. For a recent overview and basic subject areas, see: JOHN MANNING, The Emblem, London, 2002; PETER M. DALY, Emblems: An Introduction, in: Companion to Emblem Studies, (eds.) P. M. Daly, New York, 2008, 1-24. On emblems generally, see also: ÉVA KNAPP - GÁBOR TÜSKÉS (note 3), 7 ff.

\section{7}

Cf. G. RICHARD DIMLER, The Jesuit Emblem, in: Companion to Emblem Studies (note 6), 99-128.

8 ÉVA KNAPP - GÁBOR TÜSKÉS (note 3), 47.

9

Vienna was the seat of the Austrian Jesuit province, which also included Carniola, Croatia, Slavonia, Hungary, Slovakia, and Transylvania before the order's dissolution in 1773. On the Jesuits in Vienna, see: BERNHARD DUHR, Geschichte der Jesuiten in den Ländern deutscher Zunge in der ersten Hälfte des XVII. Jahrhunderts, Freiburg im Breisgau, 1913, 541ff.

10 In 1638, Pater Lamormaini (1570-1648) published a panegyric book in honour of the Emperor under the title Ferdinandi II. Romanorum imperatoris Virtutes (Vienna, Georg Gelbhaar). A Kaikavian Croatian translation of this book was produced and published only two years later by the Croatian nobleman Juraj Ratkaj under the title Kripozti Ferdinanda II. Rimzkogha Czeszara... po ottecu Gulielmusu Lamormaini diachkim iezikom zlosene... po Iuriu Rattkai, szlobodnom gozpodinu od Velikoga Thabora grada, i Zagrebachkim Canonicom Szlovinzkim iezikom popiszane (Vienna, Georg Gelbhaar, 1640). Its frontispiece features a woodcut showing the Emperor's coat of arms held by a doubleheaded imperial eagle (after a similar motif in the original). See: WERNER LEHFELDT, Juraj Ratkaj Velikotaborskis "Kripozti Ferdinanda II." im Vergleich mit ihrer lateinischen Vorlage, Göttingen, 2003. According to Lehfeldt, p. 3, Ratkaj translated only the first chapter of Lamormaini's work verbatim, with many omissions in the subsequent chapters.

11

See: CHRISTIANE ENSLE, Die Jesuitenprofessoren an der Wiener Philosophischen Fakultät (1623-1711), PhD dissertation, Univer- 
sity of Vienna, 1970, esp. XVII. See also: KURT MÜHLBERGER, Universität und Jesuitenkolleg in Wien. Von der Berufung des Ordens bis zum Bau des Akademischen Kollegs, in: Die Jesuiten in Wien. Zur Kunst-und Kulturgeschichte der österreichischen Ordensprovinz der "Gesellschaft Jesu" im 17. und 18. Jahrhundert, (eds.) H. Karner and W. Telesko, Vienna, 2003, 21-37, esp. 26ff (Pragmatic Sanction).

12

F. Polleroß speaks about "das theologische Hofmonopol der Jesuiten am Wiener Hof”. See: FRIEDRICH POLLEROß, Die Immaculata, Kaiser Leopold I. und ein römisches Thesenblatt der Laibacher Franziskaner, in: Acta historiae artis Slovenica, 23/1 (2018), 93-109, here 102. On Leopold I, see: JUTTA SCHUMANN, Die andere Sonne. Kaiserbild und Medienstrategien im Zeitalter Leopolds I., Berlin, 2003, $111 \mathrm{ff}$.

13

See: SANDRA KRUMP, Aus gegebenem Anlass... Habsburgpanegyrik in Jesuitendramen der Österreichischen Ordensprovinz. Aufgezeigt an zwei Dramen des Passauer Jesuitentheaters, in: Die Jesuiten in Wien (note 11), 165-178.

14

See: MIROSLAV VANINO, Isusovci i hrvatski narod [The Jesuits and the Croatian people], vol. 1: Rad u XVI stoljeću. Zagrebački kolegij [Activity in the $16^{\text {th }}$ century: The Zagreb College], Zagreb, 1969, 107 ff. The Jesuit secondary school was indeed attended by a large number of pupils for those times: generally, they were upwards of 500, but in 1683 more than 700 pupils were enrolled. See: FRANJO FANCEV, Građa za povijest školskog i književnog rada isusovačkoga kolegija u Zagrebu (1606-1772) [Sources for the history of educational and literary activity of the Jesuit College in Zagreb (1606-1772)], in: Starine, 37 (1934), 1-176, and 38 (1937), 181-304, here (1934), 117.

15

For emblemata symbolica produced in honour of Benedict Thuroczy, see: FRANJO FANCEV (note 14, 1934), 35. In 1619, the Jesuits produced congratulations vario symbolorum apparatu dedicated to Count Toma Erdödy. See: FRANJO FANCEV (note 14, 1934), 40. After the Count's death in 1624, the Jesuit College erected a castrum doloris in the Zagreb cathedral, where he was buried, and placed various emblems in the church (vestita variis emblematis ecclesia funebria fecit illustriora); see: FRANJO FANCEV (note 14, 1934), 50. Count Juraj Zrinski, who died in 1628, was honoured in a similar way. Although he was buried in Pozsony (today's Bratislava), the Jesuits were invited to erect a castrum doloris in St Helena's church near Čakovec, where the family tomb of the Zrinski family was situated, and to furnish the church with adequate emblems and poems (Erecto enim cenotaphio amplo et illuminato, quod vulgo castrum doloris dicitur, ecclesiam etiam varietate emblematum et elegantia carminum exornarunt); see: FRANJO FANCEV, note 14, 1934, 53. In 1639, for the funeral of Count Sigismund Erdödy, a benefactor and protector of the Zagreb College, the Jesuits installed a poster or panel with emblems (affixio amblematica) in Klanjec (cf. FRANJO FANCEV, note $14,1934,60$ ). On the funerary installations of the Jesuits, dedicated to the Emperor and other distinguished patrons and sponsors of the Society, in which emblems played a prominent role, see: LISELOTTE POPELKA, (...) Quasi per umbram objicimus. Jesuiten als Erfinder ephemerer Strukturen, in: Die Jesuiten in Wien (note 11), 147-156.

16

See: FRANJO FANCEV (note 14, 1934), 92. In 1665, quattuor propugnatores are mentioned, who defended the general tenets of Aristotle's teaching thesibus impressis. See: FRANJO FANCEV (note $14,1934), 94$. Thesis defences became more and more frequent and after 1723 defences in the fields of logic and philosophy took place almost every year, with engravings produced mainly in Augsburg (sub elegantibus augustanis emblematis). From the mid- $18^{\text {th }}$-century, theses printed in Vienna are mentioned as well (sub Viennensi emblemate). See: FRANJO FANCEV (note 14, 1937), passim.

17

On theses, see: SIBYLLE APPUHN-RADTKE, Das Thesenblatt im Hochbarock. Studien zu einer Gattung am Beispiel der Werke Bartholomäus Kilians, Weißenhorn, 1988; WERNER TELESKO, Barocke Thesenblätter, Linz, 1994; WERNER TELESKO, Thesenblätter österreichischer Universitäten, Salzburg 1996; BIRGIT ULRIKE MÜNCH, Barocke Thesenblätter, in: Handbuch Rhetorik der bildenden Künste, (ed.) W. Brassat, Berlin and Boston, 2017, 577-593; JUTTA SCHUMANN (note 12), 355-359. The term emblema was also used for other promotional materials with symbolic meaning, such as programmes, occasional allegorical panels in churches, published dissertations, and so on; see: GRETE LESKY, Frühe Embleme aus der Steiermark, Graz, 1973, 9.

18

Habita prima solemnis disputatio Prolegomenis logicae thesibus impressis proposita sub auspicijs Rmi Dni Nicolai Dijanešević, cursus istus fundatoris. See: FRANJO FANCEV (note 14, 1934), 97.

\section{9}

MIROSLAV VANINO (note 14) lists a number of such theses, or emblems as he calls them, on p. 163. His source was the Historia Collegii, edited by FRANJO FANCEV (note 14).

20

The thesis was recorded in the Historia Collegii for the year 1685. See: FRANJO FANCEV (note 14, 1934) 119; M. VANINO (note 14), 162 (description), reproduction nr. 30; also mentioned by ŠIME JURIĆ, Iugoslaviae scriptores latini recentioris aetatis, vol. 1, Zagreb, 1971, 11, nr. 77. Format of the thesis: $138 \times 100.5 \mathrm{~cm}$, printed on yellow silk, inv. nr. HPM 4260. Cf. Isusovačka baština u Hrvata [Jesuit legacy in Croatia] (exhibition catalogue), Zagreb, 1992, p. 267, cat. no. 452. I am much obliged to Marina Bregovac Pisk for her assistance with the iconographic analysis of the thesis.

21

In such prints, the Emperor is mostly represented as Jupiter in antique garments riding on an eagle. Cf. two examples in GREGOR MARTIN LECHNER, Das barocke Thesenblatt. Entstehung - Verbreitung - Wirkung. Der Göttweiger Bestand, Göttweig, 1985, no. 27: thesis or homage print to the Emperor from 1660 by Matthias Küssel; no. 40: fragment of a thesis from 1690 by Clemens Beüttler. Cf. also WERNER TELESKO (note 17, 1996), nr. 25.

\section{2}

According to C. Ripa, the symbolism of incensory is related to the personification of prayer (oratio). See: CESARE RIPA, Iconologia, Milano, 1992, 327. The personification on the Marburch's thesis is therefore a combination of pietas and oratio. On the inscription the defendant stresses the piety of the estates of Carniola to Mary Immaculate, which is confirmed by the Marian column: "Floret enim sub /Auspiciis Vestris, qui Romano illo felicius Patriae scutum / estis, Triumphata Pietas, quam magnificentissima Immacu / lata Virgini erecta nuper Statua testatur."

23

Surprisingly, the thesis is not recorded in the Historia Collegii for the respective year! It has been described by GÉZA GALAVICS, Thesenblätter ungarischer Studenten in Wien im 17. Jahrhundert. Künstlerische und pädagogische Strategien, in: Die Jesuiten in Wien (note 11), 123f. According to Galavics, the two columns were foundations made by Paul Esterházy, but FRIEDRICH POLLEROß (note 12, 102), recognises in them the Viennese Marian and Holy Trinity column. 
24

For the story of the column in Ljubljana, see: UROŠ LUBEJ, Marijin steber v Ljubljani [The Virgin's Column in Ljubljana], in: Acta historiae artis Slovenica, 6 (2001), 53-66.

25

On this, see: FRIEDRICH POLLEROß (note 12).

26

It is kept at the University library (Egyetemi Könyvtár, Kézirattár) in Budapest as Catalogus Bibliothecae Zagrabiensis Coll. S. I., BEKK J 10/20. It is not an original catalogue but rather an inventory of the Jesuit Academy library made after the dissolution of the order, and copied in 1782, as a short notice on the last folio attests: Copiavit Andr. Emer. Szathmary et finiit 19. octobrij 1782. Later on (after 1786) a comment was written on the fourth empty folio at the beginning of the inventory referring to the following decisions made by an unknown authority: "Books which are the bequest of Rev. Baltazar Krčelić to the Academy are marked with the letter K; Books which in 1786 were handed over to the Priest Seminary in Pest are marked with the letters SC; books marked with + may be left in the Zagreb Academy (retineri possunt in Accademia Zagrabiensi); all other unmarked books must be handed over to the University in Pest." Since all items within the division Poetae / symbolici, emblematici are unmarked, they probably were taken to the University in Pest.

\section{7}

ÉVA KNAPP - GÁBOR TÜSKÉS (note 3), 41, Fig. 4, table 2 (p. 272). Fig. 5 shows the cover page of Alciati's book, 1566 edition, with the ex libris of the Jesuit College in Zagreb and the year 1648. The collection in which it is preserved is not given.

28

MICHAEL-HERMANN JOSEPH GRAF VON ALTHANN, $A s$ sertiones elementares ex universa philosophia quas sub auspiciis... Imperatoris Leopoldi I... in... Universitate Viennensi publice propugnandas suscipiet... Michael Hermannus Josephus Sac. Rom. Imperii Comes ab Althann... Praeside R. P. Joann. Baptista Rösingh (etc.), Viennae: Leopold Voigt, 1689. The book is in the representative folio format. The catalogue of the Zagreb College lists it with Rösingh as its author. The consulted copy is kept in the Österreichische Nationalbibliothek, Vienna, call. nr. 507.757-D.

29

The whole-page allegorical portrait of the Emperor as the master of all the elements is signed below: E. C. Heiss del. / C. Weigel sc. Viennae. It is followed by a large, two-page table showing Cadmus killing the dragon - an allusion to Leopold and his victories over the Ottomans. In addition to this, the book contains various other two-page allegories with symbolical allusions to Leopold I. The sumptuous engravings are the work of Elias Christoph Heiss and Christoph Weigel.

30

The emblem with Darda $(285 \times 190 \mathrm{~mm})$ bears the motto TARDE EXTRAHITUR CITO PRAEDA FUTURUS. It shows a man hunting hares in their holes, with dogs. The famous wooden Turkish bridge leading from Osijek to Darda is visible and the accompanying poem is entitled Turcarum Darda erumpentium cito retardata felicitas. The emblem with Požega bears the motto $\mathrm{AD}$ DOMINUM REDEUNT ADVERSO FLUMINE. It shows three dogs swimming towards their master against the river current. The carmen (accompanying poem) is titled Enthusiasticon - Cum Possega redux Sclavonia. The emblem with Osijek bears the motto TIBI PROPRIA DESERIT UNDA. It shows fishermen catching large fish from the riverbank, as the river has withdrawn to a narrow bed. The poem is entitled Timoris emphaticon - Turcis Ossechinum deserentibus.
31

There is a myriad of depictions of the Emperor and his allies triumphing over the Ottomans, and the thesis sheets also use this popular motif. See: SIBYLLE APPUHN-RADTKE (note 17), 71; MARIA GOLUBEVA, The Glorification of Emperor Leopold I in Image, Spectacle and Text, Mainz, 2000, 122-141.

32

See: FRANZ RÖMER - ELISABETH KLECKER, Poetische Habsburg-Panegyrik in lateinischer Sprache. Bestände der Österreichischen Nationalbibliothek als Grundlage eines Forschungsprojekts, in: Biblos, 43/3-4 (1994), 183-198, esp. 186-192; FRANZ RÖMER, Poetische Habsburg-Panegyrik in lateinischer Sprache vom 15. bis ins 18. Jahrhundert, in: 1000 Jahre Österreich - Wege $z u$ einer österreichischen Identität, (ed.) F. Römer, Vienna, 1997, 91; SONJA REISNER, Die poetische Habsburg-Panegyrik in lateinischer Sprache als historische Quelle, in: Quellenkunde der Habsburgermonarchie (16.-18. Jahrhundert). Ein exemplarisches Handbuch, (eds.) J. Pauser, M. Scheutz and Th. Winkelbauer, Vienna and Munich, 2004, 898-915, esp. 908ff.

33

The original entry in the inventory is: Epithalamium Symbolicum Leopoldo I. Augusto oblatum, in. fol. 1631, with no place of printing indicated.

34

The actual title of the book is: Epithalamium symbolicum conjugibus porphyrogenitis Ferdinando III Hungarorum Boemorumque regi, serenissimae Mariae reginae, Hispaniarum infanti, cum Viennae Austriae ... regias nuptias solleniter orbe triumphante agerent..., Graz, Typis Ernesti Widmanstadii, 1631. Österreichische Nationalbibliothek, call nr. 79.B.55. The book is in the folio format and the emblems are oval, ca. $115 \times 165 \mathrm{~mm}$. The trimming is gilded and the title page bears two handwritten ex libris: Leopoldini Societatis Jesu in Austria 1668 and Ser.mo Leopoldo Gulielmo. On the book, see: LISELOTTE CAITHAML, Drei dem habsburgischen Herrscherhaus gewidmete Emblembücher der Grazer Jesuiten aus den Jahren 1609, 1618 und 1631, in: Zeitschrift des historischen Vereines für Steiermark, 83 (1992), 337-353, esp. 349-353. The article is a shortened version of the author's MA thesis: LISELOTTE CAITHAML, Drei dem habsburgischen Herrscherhaus gewidmete Emblembücher der Grazer Jesuiten aus den Jahren 1609, 1618 und 1631., Karl-Franzens-Universität Graz, vol. 2, Graz 1990, esp. 157-197.

35

Usually emblems were produced both by the novices and by their professors. This is evident from a codex containing 29 emblems made by professors and 23 by students, produced at the Graz College around 1603. The general topic was the Eucharist. Emblem nr. 49 stems from Christophorus Bedekovich de Komor Nob. Croata, a student from the poetry class. In his emblem, the Eucharist is linked to the expulsion of the Protestants from Lower Austria! Nowadays the codex is preserved in Vienna, Österreichische Nationalbibliothek, Codex Vindobonensis 10.178. See: GRETE LESKY, Frühe Embleme aus der Steiermark, Graz, 1973, passim.

36

The lyre also appears in the emblem SINE FELLE HYMEN, where it is called Arion's lyre in the explanation. A dolphin is carrying it across the sea on its back. The author wishes the betrothed couple a marriage as harmonious as the sound of Arion's lyre.

37

"Equidem dum genus Austrium, dum Societas Jesu vivet, vigebat in eijusdem posteris gratissimus animus...." 
38

For instance, the inventory of the Zagreb College lists two more panegyric publications, dedicated to Leopold I and his newborn son Joseph I. The catalogue entries are as follows: Anonymi (ord. S. August.), Applausus Leopoldo I. Regno Bohemiae Diadema sumenti, in quarto, 1656, Prague; Josephi Aegyptii virtutes in Josepho I. Augusto convenientes, in fol., $1690 \mathrm{Graz}$. In this context, it should be emphasized that no printing office was active in Zagreb before the end of the $17^{\text {th }}$ century.

39

On Glavinić, see: Hrvatski biografski leksikon [The Croatian biographic lexicon], Zagreb, 1998, vol. 4, 740-742 (author of the entry: Pejo Cošković).

40

Having returned from his journey, he wrote an exhaustive report on the situation in the Muscovite state: Relatio de rebus Moscoviticis cum epistola ad Leopoldum I imp. Österreichische Nationalbibliothek, call. nr. Cod. 8578.

41

In this period, Glavinić composed a manuscript listed as Interpretatio altaris portatilis Russorum. Österreichische Nationalbibliothek, call nr. Cod. 10214k. The manuscript consists of a single large sheet, ca. $60 \times 52 \mathrm{~cm}$, and describes the way in which the Russians pray and make their holy icons and altars. The sheet was presented to Emperor Leopold I on New Year's Day 1670. At the bottom of the main text, there is a signature: Humillimus subdictus ac Capellanus Sebastianus Glauinich Istrianus Petinensis.

\section{2}

SEBASTIAN GLAVINICH, Deplua charitum aurora augustissimi Phoebi Leopoldi augusto rore in Margaritam resoluta: auspicatissimis toris... Leopoldi et... Margaritae... oblate. Printed by Susanna Rickesin, Vienna, 1666. There is a copy in the Österreichische Nationalbibliothek, call nr. ${ }^{\star} 46$. Q.25., with an ex libris on the title page: Collegij Neostadiensi Soc. Jesu 1705. Documented in: ŠIME JURIĆ, Južnoslavenski latinski pisci novovjekovlja. Dio I. Djela hrvatskih latinskih pisaca tiskana do 1848. godine-Iugoslaviae scriptores latini recentioris aetatis. Pars I. Opera scriptorum latinorum natione Croatarum usque ad annum MDCCCXLVIII typis edita, vol. 1-3, 1968-82, additamentum I, Zagreb, 1982, p. $61, \mathrm{nr} .269$ (in this bibliography, the first word in the title is transcribed wrongly: it is not "De pia", but "Deplua"). The book is mentioned in: SIBYLLE APPUHN-RADTKE, Allegorie und Emblem, in: Quellenkunde der Habsburgermonarchie (note 32), 971-1005, here 987.

43

ROSTISLAV SMÍŠEK has written an extensive study on Glavinić's panegyrics: Deplua Charitum Aurora. Leopold I. a Markéta Tereza Spanělská v symbolické řeči gratulačního spisu Sebastiana Glaviniće k jejich sňatku roku 1666 [Deplua Charitum Aurora: Leopold I and Margarita Teresa of Spain in the symbolic speech of Sebastian Glavinić's congratulation on their marriage in 1666], in: Listy filologické, 1-2 (2014), 41-71. However, this article does not include emblem reproductions and the order of emblems 7 and 8 has been reversed.

44

There is a copy preserved at the Österreichische Nationalbibliothek, call nr. 50.C.17. The book is mentioned by SIBYLLE APPUHN-RADTKE (note 42), 987.

45

See: FRIEDRICH WILHELM HOLLSTEIN, German Engravings, Etchings and Woodcuts, ca. 1450-1700, vol. 18 (compiled by Robert Zijlma), Amsterdam, 1976, nr. 605-612. In Hollstein only 8 emblems are attributed to $\mathrm{Ph}$. Kilian. Albinus Patho signed the allegorical engraving in front of the page with the dedicatory text with the remark delin[eavit]. Ph. Kilian signed this engraving with sculpsit as well as 9 of the 11 emblems. Emblems with lavishly ornamented frames occupy a whole page (ca. $320 \times 200$ $\mathrm{mm}$ ). In terms of artistic skills, these emblems are incomparably finer than those of Glavinić and even those from Graz published in 1631. In the Vienna copy of the book there is a whole-page frontispiece portrait of the Emperor in the mezzotinto technique, dated Augsburg 1698, made by Elias Christophorus Heiss (1660-1731, signed below on both sides) - See: FRIEDRICH WILHELM HOLLSTEIN, German Engravings, Etchings and Woodcuts, ca. 1450-1700, vol. 13 (compiled by Robert Zijlma), Amsterdam, 1984, nr. 67. The portrait must have been inserted at a later time.

46

The emblems are horizontal ovals with no ornamentation, engravings, ca. $100 \times 135 \mathrm{~mm}$ (plate), with mottos incised in the upper section.

47

For example, several symbolic motifs come from DIEGO FAXARDO DE SAAVEDRA, Idea principis christiano-politici centis symbolis expressa, Bruxelles, 1649 (and later editions) as well as other emblem collections, such as Alciati, Camerarius and Ripa. See: ROSTISLAV SMÍŠEK (note 43), 67.

48

SANDRA KRUMP (note 13), 165

49

With Glavinić, the Emperor's military strength is praised only in his emblem HINC TONAT, INDE MICAT, but the enemies are not clearly identified as the Ottomans. The omission of a laudatory emblem dedicated to the battle of St Gotthard may indicate Glavinićs dissatisfaction with the Treaty of Vasvár (1664) between the Empire and the Ottomans, which the Croatian and Hungarian magnates considered as shameful.

50

Interpretation according to: SIBYLLE APPUHN-RADTKE (note 42), $987 \mathrm{ff}$.

51

The poetical content of Glavinić's emblems has been analysed by ROSTISLAV SMÍŠEK (note 43). I am grateful to Ana Plosnić Škarić for helping me in better understanding the meaning of the Latin verses.

52

The symbolic motif was probably inspired by DIEGO FAXARDO DE SAAVEDRA (note 47), emblem XXXIII.

53

This emblem was probably inspired by JACOB TYPOTIUS, Symbola Divina et Humana Pontificum, Imperatorum, Regum, Egidius Sadeler, Prague, 1601-1603. Symbols and emblems of the Eucharist are at the very beginning of Typotius' collection.

54

On the Habsburg veneration of the Eucharist (pietas eucharistica), see: ANNA CORETH, Pietas Austriaca. Österreichische Frömmigkeit im Barock, Vienna, 1982 ( $2^{\text {nd }}$ edition), 18 ff.; KARL VOCELKA and LYNNE HELLER, Die Lebenswelt der Habsburger. Kultur-und Mentalitätsgeschichte einer Familie, Graz, 1997, 18ff. On the pietas Eucharistica (and pietas Mariana) at the time of Leopold I, see especially: SIBYLLE APPUHN-RADTKE (note 17), 71.

\section{5}

Cf. SIBYLLE APPUHN-RADTKE (note 17), 67. The author mentions Glavinićs book and this emblem as an example of using the two-column motif. 


\section{6}

This motif probably derives from Typotius' emblem with the inscription PRVDENTIA, in the group of emblems dedicated to the Holy Cross. See: J. TYPOTIUS (note 53), table 5.

57

A contemporary of Glavinić, Pavao Ritter Vitezović from Senj, tried to do something similar in his Nova Musa, sive Pars artificiosa operum poeticarum, Vienna, 1683, where he published several panegyrical poems. The first and longest is dedicated to Emperor Leopold I, and another, somewhat shorter, to his son Joseph. Vitezović's intention was to earn the title of poeta laureatus and a position at court with his poetic laudations, which would have secured him a steady income, but he only received a single gift of 100 forints from the Emperor. See: VJEKOSLAV KLAIĆ, Život i djela Pavla Rittera Vitezovića (1652.-1713.) [The life and work of Pavao Ritter Vitezović (1652-1713)], Zagreb, 1914, 40ff.

\section{Sažetak}

\section{Milan Pelc \\ Panegirički amblemi i habsburški carevi - primjeri iz 17. stoljeća povezani s hrvatskom kulturnom sredinom}

U radu je s pomoću dostupnih izvora informacija predstavljeno i analizirano nekoliko publikacija s panegiričkim amblemima kojima se promovira habsburška carska kuća u 17. stoljeću, a povezane su sa (sjeverno)hrvatskim kulturnim područjem. Knjige s amblemima nisu se objavljivale $u$ Hrvatskoj, ali su se dobavljale u prvom redu za isusovačke kolegije i u njima su se koristile. Osim toga, amblemima su se označavale i druge prigodne vizualne instalacije (primjerice alegorijski prikazi u crkvama posvećeni nekom aristokratskom pokrovitelju) i publikacije nastale u sklopu isusovačkog obrazovanja i drugih potreba vizualne prezentacije. Poput svih isusovačkih učilišta i zagrebačka je akademija poticala svoje doktorande da objavljuju tiskane teze u obliku velikih plakatnih listova (Thesenblätter) koji su se javno izlagali na obrani disertacije i poklanjali odabranim primaocima. Prema sačuvanim povijesnim dokumentima u razdoblju od osnutka studija filozofije 1663. pa do ukinuća reda 1773. godine tiskani su za zagrebačke studente mnogi takvi listovi u tehnici bakroreza, najčešće kod izdavača u Augsburgu. U godišnjim kronikama zagrebačkog kolegija ti se listovi vrlo često označavaju kao emblema. Takvi su učeni "plakati” bili osobito prikladni za promociju aristokratskih pokrovitelja isusovačkog reda i samog vladara. Nažalost u Hrvatskoj se sačuvao vrlo mali broj primjeraka listova s tezama. Među njima u 17. stoljeću najreprezentativnija je teza Riječanina Ivana Josipa Marburcha (Marburga) iz 1685. godine pod naslovom Theses ex universa Philosophia velikoga plakatnog formata (emblemate praegrandi!). Jedan luksuzni primjerak te teze, tiskan na žutoj svili, sačuvan je u Hrvatskom povijesnom muzeju. Premda je teza bila posvećena kranjskim staležima (defendent je bio podrijetlom iz Rijeke, a Rijeka je pripadala Kranjskoj), car Leopold I. prikazan je u gornjem dijelu kompozicije na oblaku s orlom ne samo kao vrhovni pokrovitelj branitelja teze nego i čitavog carstva.

U popisu knjiga iz knjižnice isusovačkog kolegija u Zagrebu, načinjenom u drugoj polovini 18. stoljeća (danas u Budimpešti), zabilježene su brojne knjige amblemskog sadržaja objavljene od 16. do 18. stoljeća. U zabilježenim naslovima amblemskih knjiga zagrebačkog kolegija lako je prepoznati primjerke panegiričkoga i laudacijskog karaktera, posvećene veličanju careva Ferdinanda III. i Leopolda I. Zagrebački kolegij posjedovao je, primjerice, posebno izdanje doktorskih teza bečkog doktoranda, grofa Michaela-Hermanna Josepha Althanna iz 1689. godine iz opće filozofije: Assertiones ex universa philosophia. Alegorije i amblemi s panegiričkopovijesnim komentarima i popratnim pjesmama u toj luksuznoj knjizi s velikim bakrorezima posvećeni su pobjedama Leopolda I. nad Turcima u Ugarskoj i Slavoniji.

S 'mirnodopskog' područja života habsburških vladara u 17. stoljeću osobito su zanimljive panegiričke publikacije epitalmijske vrste kao omiljen medij za iskazivanje počasti vladaru u presudnom trenutku dinastičke povijesti, u kojem se ženidbom trebalo osigurati političko savezništvo i nasljednika na prijestolju. U radu su predstavljena dva primjera s područja epitalamijske panegiričke amblematike koja se mogu povezati i s Hrvatskom. Prvi po tome što je zabilježen u katalogu zagrebačkoga kolegija. Riječ je o knjizi Epithalamium Symbolicum Leopoldo I. Augusto oblatum, objavljenoj u Grazu 1631. godine. Knjigu su pripadnici isusovačkog kolegija u Grazu posvetili vjenčanju kralja i kasnijeg cara Ferdinanda III. (1608.-1657.) i Marije Ane Španjolske (1606.-1646.). Drugu je knjigu sastavio i objavio Sebastijan Glavinić (1632.-1697.), kasniji senjski i modruški biskup, koji se školovao na isusovačkim akademijama u Grazu, Beču i Trnavi. Kao dvorski kapelan u Beču, Glavinić je u prigodi vjenčanja cara Leopolda I. sa španjolskom princezom Margaritom Terezom 1666. godine sastavio panegiričku brošuru s deset amblema posvećenu carskom paru. Kao privatna osoba u carskoj službi Glavinić je zacijelo smatrao da će mu takvo iskazivanje odanosti učvrstiti položaj na dvoru i donijeti nove beneficije. To se i dogodilo kad ga je 1689. godine Leopold I. postavio za biskupa Senjsko-modruške biskupije. Vjerojatno je toj carevoj odluci pridonijela i mala panegirička knjižica s amblemima kojom je Glavinić, isusovački đak i sljedbenik isusovačkih metoda, uzorno demonstrirao lojalnost svojemu vladaru.

Ključne riječi: amblemi, habsburški vladari, isusovci, Sebastijan Glavinić 


\section{Izvori ilustracija i autori fotografija / Sources of illustrations and photo Credits}

\begin{abstract}
Višnja Bralić
The Cult of Saint Euphemia, the Patron Saint of Rovinj, and the Venetian Politics of Co-creating Local Identities in Istrian Communities in the $15^{\text {th }}$ Century / Kult sv. Eufemije, zaštitnice Rovinja $i$ venecijanska politika sukreiranja lokalnih identiteta u istarskim zajednicama 15. stoljeća
\end{abstract}

1: (c) Museo Correr, Venezia (Giuseppe Rosaccio, Viaggio da Venezia a Costantinopoli, per mare e per Terra, \& insieme quello di Terra Santa, Venetia: Giacomo Franco, 1598, fol. 7v)

2-10: Ljubo Gamulin

\section{Anna Boreczky}

Historiography and Propaganda in the Royal Court of King Matthias: Hungarian Book Culture at the End of the Middle Ages and Beyond / Historiografija i propaganda na dvoru kralja Matije Korvina. Mađarska kultura knjige krajem srednjega vijeka i dalje

1-11, 14, 16-18: @ National Széchényi Library, Budapest (Országos Széchényi Könyvtár)

12, 13: ( ) Heidelberg University Library (Universitätsbibliothek Heidelberg)

15: From Wikimedia Commons, the free media repository

\section{Ivan Gerát}

Saint George Between Media and Functions / Sv. Juraj izmedu medija i funkija

1: Image courtesy National Gallery of Art, Washington DC

2: https://www.metmuseum.org/art/collection/, Public Domain

3: https://www.metmuseum.org/art/collection/, Public Domain

4, 5: Ivan Gerát

6: Archive of the Institute of Art History of the Slovak Academy of Sciences

\section{Ivan Ferenčak}

The Illustrations in the Glagolitic Books Printed by Bishop Šimun Kožičić Benja in Rijeka (1530-1531) / Ilustracije u glagoljskim knjigama biskupa Šimuna Kožičića Benje tiskanim u Rijeci (1530.-1531.)

1: Tamara Runjak, Rijetkosti u Knjižnici Hrvatske akademije znanosti i umjetnosti: katalog inkunabula i knjiga 16. stoljeća, Zagreb, 2011.

2, 7-10: Zagreb, Knjižnica Hrvatske akademije znanosti i umjetnosti, R-600, snimio Ivan Ferenčak 2019.

3: Ivan Ferenčak, 2019.

4: Biblioteca nazionale Marciana, Venezia, BM - Rari Ven. 579 (su concessione del Ministero per i Beni e le Attività Culturali - Biblioteca Nazionale Marciana. Divieto di riproduzione).

5: Biblioteca nazionale centrale di Firenze, Firenze, MAGL.2.1.109 (su concessione del Ministero dei beni e delle attività culturali. Biblioteca Nazionale Centrale di Firenze. Divieto di riproduzione)
6: Bibliothèque nationale de France, Paris, département Musique, RES-1527.

11: Nacionalna i sveučilišna knjižnica, Zagreb, RIIA- $8^{\circ}-8$.

12: Nacionalna i sveučilišna knjižnica, Zagreb, RIIA-16º-5.

\section{Milan Pelc}

Panegyric Emblem Books, Jesuits and the Habsburg Emperors: Some Examples Related to $17^{\text {th }}$-Century Croatia / Panegirički amblemi $i$ habsburški carevi - primjeri iz 17. stoljeća povezani s hrvatskom kulturnom sredinom

1: ๔ Hrvatski povijesni muzej, Zagreb / Croatian History Museum 2: ( University Library, Budapest / Egyetemi Könyvtár, Kézirattár 3-20: ๑ Austrian National Library, Vienna / Österreichische Nationalbibliothek

\section{Polona Vidmar}

Coesari in mis omni hora fidelis servivi: The Portraits of Sigismund Herberstein and Walter Leslie in Diplomatic Robes / Cæsari in mis omni hora fidelis servivi: Portreti Žigmunda Herbersteina $i$ Waltera Leslieja u diplomatskim odorama

1-2, 4, 6: Knjižnica Ivana Potrča Ptuj / Ivan Potrč Library Ptuj 3: Hollstein's German Engravings, Etchings and Woodcuts 1400-1700, vol. XIII A, 1984

5, 10, 13: Google Books

7-9, 11-12: Polona Vidmar

\section{Nóra G. Etényi}

Broadsheets with Engravings in a Manuscript Chronicle from Ulm: Visual Representations of the Hungarian Kingdom on German Political Leaflets during the War of Reconquest (1683-1699) / Grafički plakati u rukopisnoj kronici iz Ulma: Vizualna reprezentacija Ugarskog Kraljevstva na njemačkim političkim letcima tijekom Velikog turskog rata (1683.-1699.)

1, 4: (C) Austrian National Library Portrait Collection, Vienna / Österreichische Nationalbibliothek Porträtsammlung

2, 3, 6: @ Hungarian National Museum, Budapest / Magyar Nemzeti Múzeum

5, 7: @ National Széchényi Library, Budapest, Apponyi Sammlung / Országos Széchényi Könyvtár, Apponyi Metszet

\section{Werner Telesko}

Graphic prints of the Josephine period (1765/1790) and the propaganda of 'Religious Tolerance' / Grafički listovi Jozefinskog razdoblja (1765./1790.) i propaganda "Vjerske tolerancije"

1: ( ) Austrian National Library, Vienna

2: () Austrian National Library, Vienna

3: ㄷ Vienna Museum 
4: (C) Vienna Museum

5: (C) Vienna Museum

6: C Vienna Museum

\section{Martina Frank}

Representing the Republic in Seventeenth-Century Venice / Predstavljanje Republike u Veneciji 17. stoljeća

1, 3, 4, 5, 12: @ Austrian National Library, Vienna / Österreichische Nationalbibliothek

2, 15: Martina Frank

6: () University Library of Padua / Biblioteca universitaria di Padova

7: @ McNay Art Museum

8: Cat Bauer (https://venetiancat.blogspot.com/2016/11/thanksgiving-in-venice-celebrates-black.html)

9, 10: https://www.lamoneta.it/topic/157941-medaglia-nicol\% C3\%B2-contarini/

11: ๑ José Luiz Bernardes Ribeiro / CC BY-SA 4.0

13: Internet culturale

14: () Marciana National Library / Biblioteca Nazionale Marciana, Venezia

16: ( ) Museo Civico del Castello di San Giusto, Trieste

\section{Bálint Ugry - Maja Žvorc}

The Čakovec Stone Bust Collection: New Identifications, Possible Dating and the Identity of its Commissioner / Zbirka kamenih bisti u Čakovcu: Nove identifikacije, moguće datacije i naručitelj

1, 4, 6, 8, 10: Jovan Kliska

2: ๑ Austrian National Library (Österreichische Nationalbibliothek), Vienna

13, 15: ( ) Museum of Međimurje (Muzej Međimurja), Čakovec

3, 5, 7, 9, 11, 14, 16: Corpus Juris Hungarici, Tyrnaviae, 1751.

12: ( National Széchényi Library (Országos Széchényi Könyvtár), Budapest

17, 18: @ National Archives of Hungary (Magyar Nemzeti Levéltár), Budapest

19: Bálint Ugry

\section{Damir Tulić}

Glory Crowned in Marble: Self-promotion of Individuals and Families in Seventeenth- and Eighteenth-Century Monuments in Istria and Dalmatia / Slava okrunjena mramorom: Samopromocija osoba $i$ obitelji na spomenicima 17. i 18. stoljeća u Istri i Dalmaciji

1, 2, 3, 4, 5, 6, 7, 8, 9, 10, 11, 12, 13, 15, 16, 17: Damir Tulić

14: Samo Štefanac

\section{Jasminka Najcer Sabljak}

Portraits of Habsburg Rulers in the Aristocratic Collections of Eastern Croatia / Portreti vladara obitelji Habsburg u plemićkim zbirkama istočne Hrvatske

\author{
1, 2: ( $)$ Galerija Matice srpske, Novi Sad \\ 3: Francisca Clary-Aldringen \\ 4: Davor Šarić
}

\section{Danko Zelić}

Projekt Fausta Vrančića za opsadu Ostendea iz 1603. godine / Faust Vrančićs Design for the Siege of Ostend from the Year 1603

1: Matthias Dögen, Architectura militaris moderna (...), Amstelodami, 1647., 354-355.
2-4: ( ) Rijksarchief in België / Archives de l'État en Belgique, Algemeen Rijksarchief / Archives générales du Royaume, Fond Duitse Staatssecretarie / Secrétairerie d'État Allemande, 413, p. 309

5: Pompeo Giustiniano, Delle guerre di Fiandra libri 6. Di Pompeo Giustiniano del Consiglio di guerra di S. M. C. (...) Posti in luce da Gioseppe Gamurini (...) con le figure delle cose più notabili, In Anversa, 1609., 84-85

\section{Radoslav Tomić}

Generalni providur Leonardo Foscolo i umjetnost u Dalmaciji / Provveditore generale Leonardo Foscolo and Art in Dalmatia

1-30: Fotografije iz arhive autora

4: Presnimak iz: Alfons Pavich pl. Pfauenthal, Prinosi povijesti Poljica, Sarajevo, 1903., 79.

\section{Petar Puhmajer}

Dvorac Cernik - kontinuitet i mijene predturskog nasljeđa u barokno doba / The Cernik Castle - Continuity and Change in the Pre-Ottoman Heritage during the Baroque Era

1, 2, 9: Paolo Mofardin, Fototeka IPU

3 a, b; 6 a , b c c, d: arhitektonski snimak Sanja Štok i Barbara Kulmer, grafička obrada Marin Čalušić

4, 7, 10, 11: Petar Puhmajer

5: ๑ Generallandesarchiv, Karlsruhe

\section{Bojan Goja}

Kuća Cattinelli 1772. godine: prilog poznavanju stambene arhitekture u Zadru u 18. stoljeću /

The Cattinelli House in 1772: A Contribution to Our Knowledge of Housing Architecture in $18^{\text {th }}$-Century Zadar

1, 2: Bojan Goja

3, 4: Branko Maroević, dipl. ing. arh., izrada nacrta

\section{Iva Pasini Tržec}

Slike starih majstora iz zbirke Ervina i Branke Weiss u Strossmayerovoj galeriji u Zagrebu / Paintings of Old Masters from the Collection of Ervin and Branka Weiss in the Strossmayer Gallery in Zagreb

1, 3, 6: Arhiv Strossmayerove galerije HAZU, dokumentacija Weiss 2: MAK - Museum of Applied Arts (Museum für angewandte Kunst), Vienna

4: RKD - Netherlands Institute for Art History (Rijksbureau voor Kunsthistorische Documentatie), Den Haag

5: Palais Liechtenstein, Vienna

6: ( ) Strossmayerova galerija starih majstora HAZU

7: BDA - Bundesdenkmalamt Archiv (Federal Monuments Authority Austria Archive), Vienna

\section{Irena Kraševac}

Prva tri djela u fundusu Moderne galerije Društva umjetnosti / The First Three Artworks in the Holdings of the Modern Gallery of the Art Society in Zagreb

1, 4: Goran Vranić, Moderna galerija, Zagreb

2: Paolo Mofardin, Institut za povijest umjetnosti, Zagreb

3: digitalna presnimka iz kataloga izložbe: Ivan Meštrović. Skulpturen, Nationalgalerie, Staatliche Museen Preußischer Kulturbesitz, Berlin, 1987. (Nenad Gattin?)

5: Arhiv Galerije grada Praga / Archive of Prague City Gallery 